A. Queffelec, P.I Bertran, T. Bos, and L. Lemée. Mineralogical and organic study of bat and chough guano: implications for guano identification in ancient context. Journal of Cave and Karst Studies, v. 80, no. 2, p. 1-17. DOI: 10.4311/2017ES0102

\title{
MINERALOGICAL AND ORGANIC STUDY OF BAT AND CHOUGH GUANO: IMPLICATIONS FOR GUANO IDENTIFICATION IN ANCIENT CONTEXT
}

\author{
Alain Queffelec ${ }^{1, C}$, Pascal Bertran ${ }^{1,2}$, Teddy Bos ${ }^{3}$, and Laurent Lemée ${ }^{4}$
}

\begin{abstract}
The mineralogical and geochemical evolution of cave guano deposits in France has been investigated in detail. Two test pits were excavated in guano mounds from insectivorous bats and one in a guano mound from omnivorous choughs. Both bats and choughs are thought to be among the main accumulators of guano during the Pleistocene in southwest France. Thin section analysis, mineralogical identification and quantification, geochemical analysis, organic matter characterization through pyrolysis and thermochemolysis coupled to gas-chromatography, were conducted to better understand the evolution of guano in caves and to identify the underlying factors. Bat guano undergoes mineralization through loss of organic matter and precipitation of phosphate and sulfate minerals. The neoformed minerals include gypsum, ardealite, brushite, francoanellite, hydroxylapatite, monetite, newberyite, and taranakite, and vary according to the local availability of chemical elements released by the alteration of detrital minerals due to acidic solutions. Chough guano, located at higher altitude in a periglacial environment, does not show similar mineral formation. Organic geochemical analysis indicates strong differences between guano. Abundant hydrocarbons derived from insect cuticles were the dominant feature in bat guano, whereas a mostly vegetal origin typifies chough guano. Geochemical analysis points to an especially high content of copper and zinc in bat guanos, a few hundreds of $\mu \mathrm{g} / \mathrm{g}$ and thousands of $\mu \mathrm{g} / \mathrm{g}$, respectively. Both organic matter analysis and geochemistry may help identification of bat guano in archeological contexts, where phosphate minerals can originate from multiple sources.
\end{abstract}

\section{Introduction}

Sediments in karstic caves often contain large amounts of phosphate minerals that have been exploited and used as fertilizer for centuries. Excrement (guano) from cave animals, especially bats, has long been designated as the primary source of phosphate accumulation in caves (Hutchinson, 1950; Hill and Forti, 1997). Detailed mineralogical inventories have been made and a large diversity of mineral species have been identified worldwide in caves (Bridge, 1973; Balenzano et al., 1976; Fiore and Laviano, 1991; Onac et al., 2001; Karkanas et al., 2002; Onac et al., 2005, 2009; Dumitraş et al., 2008; Puşcaş et al., 2014; Wurster et al., 2015). Some of these studies focused on Paleolithic sites from Western Europe and the Near East, where phosphates form diffuse concentrations in the sediments (such as macro or microscopic nodules), or occur as stratiform units of varying thickness and hardness. In contrast, only a few actualistic studies deal with guano alteration and the redistribution of alteration products within the sediment, which leads to the formation of authigenic minerals (Shahack-Gross et al., 2004; Wurster et al., 2015). A detailed understanding of these processes is, however, of paramount importance for the study of cave sites and for the evaluation of the alteration of archeological artifacts due to the percolation of phosphate and sulfate solutions. Phosphate dynamics may also impact the isotopic and palynological record preserved in guano-rich sediments used for paleoenvironmental studies (Mizutani et al., 1992; Carrión et al., 2006; Bird et al., 2007; Wurster et al., 2008; Geantă et al., 2012; Forray et al., 2015; Royer et al., 2017).

Insofar as bats are currently the main accumulators of phosphate in caves, and since their geographical distribution covers almost all terrestrial environments (Parker et al., 1997), this study focuses on the analysis of bat guano and its diagenesis in limestone context. A comparison is made with guano of choughs, which are another potential phosphate accumulator in caves. The analysis combines micromorphology, mineralogy and chemistry in an attempt to better understand the degradation of guano in caves located in southwest France, in a humid temperate climate (bat guano), or in a high-altitude periglacial area (chough guano). This multiproxy analysis allows us to propose new criteria from geochemistry and organic matter composition for the identification of bat guano origin of authigenic minerals in the fossil record, in addition to the sole mineralogy used so far.

\section{Geological Setting of the Selected Sites}

La Fage and Rancogne caves (Fig. 1) are both located at low altitude (300 and $88 \mathrm{~m}$ above sea level, respectively) in Mesozoic (Bajocian) oolitic limestones in the Aquitaine Basin, France (Lefavrais-Raymond et al., 1976; Le Pochat et al., 1986) (mean annual air temperature $=12{ }^{\circ} \mathrm{C}$, mean annual precipitation $\approx 877 \mathrm{~mm} \mathrm{y}^{-1}$ ). La Fage Cave, which yielded

\footnotetext{
'Université de Bordeaux, PACEA-UMR CNRS 5199, avenue Geoffroy Saint-Hilaire, 33615 Pessac, France

${ }^{2}$ Inrap, 140 avenue du Maréchal Leclerc, 33130 Bègles, France

${ }^{3}$ Service Archéologique - Toulouse Métropole, 37 chemin Lapujade 31200 Toulouse, France

${ }^{4}$ Université de Poitiers, IC2MP - UMR CNRS 7285, Poitiers, France

cCorresponding Author: alain.queffelec@bordeaux.fr
} 


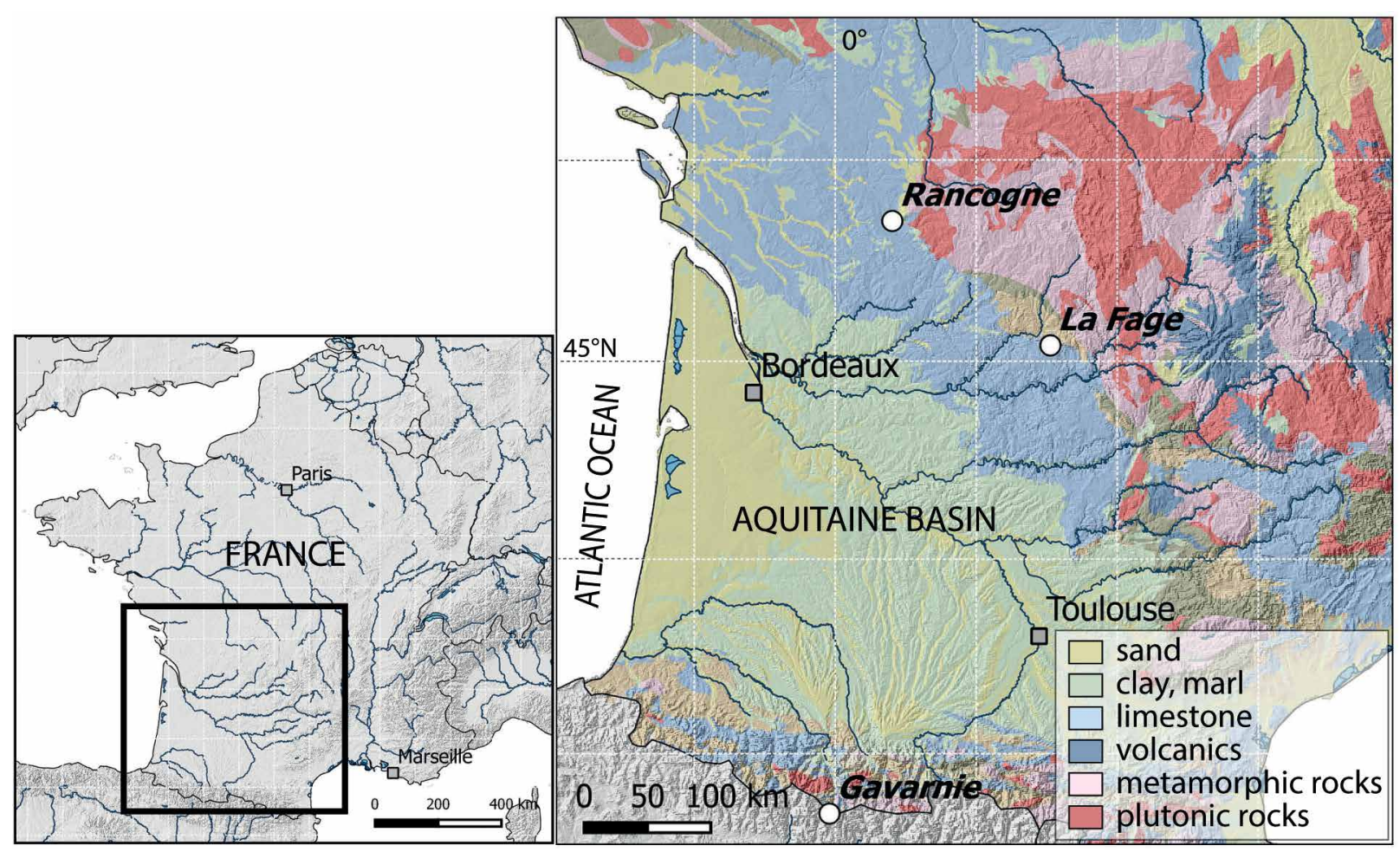

Figure 1. Location of the studied sites.

Middle Pleistocene paleontological remains (Beaulieu et al., 1973), presently shelters a large and multispecies colony of bats. The studied cross section, located ca. $100 \mathrm{~m}$ from the entrance, was dug to the limestone substrate in a still active, $70 \mathrm{~cm}$ thick guano mound (Fig. 2a). In Rancogne Cave, the sampled test pit was also made in an active guano mound (Fig. 2b). Sedimentation in this site is still influenced by the floods of the Tardoire River, as testified by blankets of alluvial silt in the karst conduit and input of detrital sediment in the guano piles. However, these floods are not strong enough or frequent enough to destroy the guano mounds. Intense biological activity took place at the surface of the mound, which was covered by larvae of dung-feeding insects. Bats from both caves are insectivorous species, mostly Minopterus schreibersii.

Gavarnie Cave is located in the central Pyrenees (Fig. 1), approximately $2900 \mathrm{~m}$ above sea level, and opens in a wall of dolomitized limestone (mean annual air temperature $=0{ }^{\circ} \mathrm{C}$, mean annual precipitation $\approx 1800 \mathrm{~mm} \mathrm{y}^{-1}$ ). Chough (Pyrrhocorax graculus) is a small, social corvid currently found only in mountainous areas, but which was present at much lower altitude during the Pleistocene (Laroulandie, 2004). Its diet consists mainly of insects (Coleoptera, Ortho-
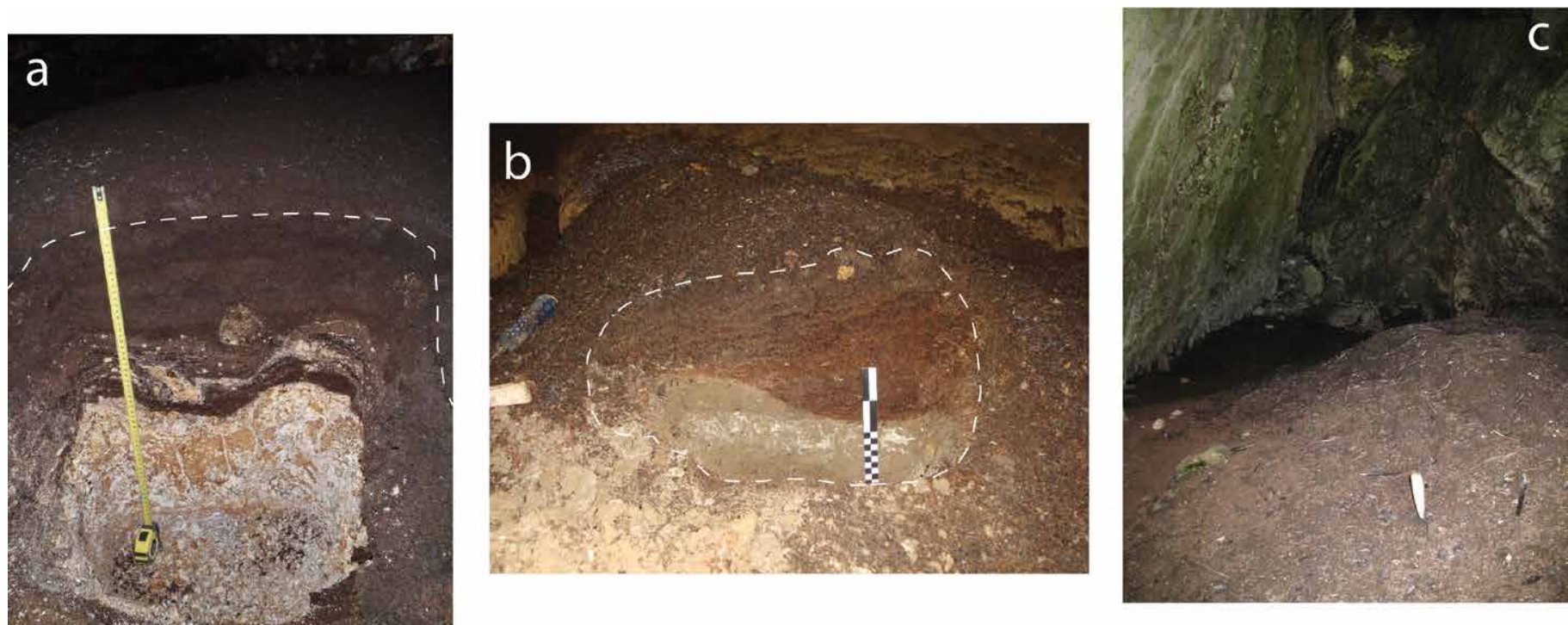

Figure 2. Three guano mounds: (a) La Fage Cave (bat guano), scale is $60 \mathrm{~cm}$ long; (b) Rancogne Cave (bat guano), scale bar is $20 \mathrm{~cm}$ long; (c) Gavarnie Cave (chough guano); trowel is $20 \mathrm{~cm}$ long. The top of the pit is indicated by the dashed line. 
ptera and Diptera) and berries (Dendaletche, 1997; Géroudet, 2010). The guano accumulation, $1.5 \mathrm{~m}$ thick, is located a dozen meters from the cave entrance, and guano is mainly composed of vegetal debris and feather remains (Fig. 2c). Except in the upper $30 \mathrm{~cm}$ of the mound, abundant lenses of segregation ice were observed within the organic accumulation. Since the field observations were made in September, at the end of the summer, ice obviously indicates that the mound remained perennially frozen. A cold trap-like behavior of the cave, due to its descending configuration (cold heavy air rapidly enters the cave in winter, in contrast to warm air in summer), is thought to be responsible for this micro-environment.

\section{Methods}

Sections were cleaned and described in detail. Blocks of undisturbed sediment were sampled for micromorphological study. The thin sections (up to $7 \times 13 \mathrm{~cm}$ ) were prepared after drying and impregnation of the samples with a polyester resin, following Guilloré's method (1980). Observation was conducted with a Leica DM2500P petrographic microscope and the LAS V4 software.

The mineralogical composition of the sediment was studied by X-ray diffraction on ground samples in a silicon, calibrated PANalytical X'Pert diffractometer, using the Ka 1 of a copper anticathode operated at $40 \mathrm{kV}$ and $40 \mathrm{~mA}$. Thirty minutes of measurement for each sample allowed for the spectra to be collected from $8^{\circ}$ to $80^{\circ}(2$ theta) with a resolution of $0.02^{\circ}$. Mineralogical identification was made by comparison with the JCPDS-ICDD database using the DIFFRACPLUS Eva software. The TOPAS software, based on Rietveld's (Rietveld, 1969) method, allowed quantification of the different mineral phases. Quantification was performed only on samples containing low amounts of short-range ordered material and only for crystalline phases.

The $\mathrm{pH}$ was measured following Baize's (Baize, 2000) method on a suspension of $2 \mathrm{~g}$ of sediment in $10 \mathrm{~g}$ of water, using a $\mathrm{pH}$-meter, calibrated with buffer solutions at $\mathrm{pH} 4$ and $\mathrm{pH} 7$.

The Total Organic Carbon (TOC) and sulfur (S) content was measured by pyrolysis $\left(1500^{\circ} \mathrm{C}\right)$ coupled with infrared spectrometry using a Leco CS-125 analyzer, after hydrochloric acid treatment to remove the carbonates. In addition, the organic matter content was obtained from the dried sample by calcination at $650{ }^{\circ} \mathrm{C}$ for $4 \mathrm{~h}$. The Loss-On-Ignition (LOI) is the loss of sample mass during the process.

Semi-quantitative, geochemical analysis was made by Energy Dispersive X-Ray Fluorescence (ED-XRF) and compared with the XRD results. The lack of specific calibration of the machine for this kind of organic-, sulfur- and/or phosphate-rich samples did not allow a fully quantitative approach. Therefore, the values must be taken as approximate and were complemented by the observation of spectra. The analyses were performed in 60 seconds on powdered samples with a Spectro X-SORT instrument, equipped with a tungsten (W) X-ray tube, run at $40 \mathrm{kV}$ and $0.01 \mathrm{~mA}$.

The organic matter was characterized at the molecular scale using on-line pyrolysis and thermochemolysis. The crushed sample was placed in a stainless-steel cup. Pyrolysis took place at $600{ }^{\circ} \mathrm{C}$ for one minute in a Frontier Lab (EGA PY 3030D) pyrolyzer equipped with an AS-1020E auto sampler and directly coupled to a quadrupolar Shimadzu QP2010 Ultra GC/MS. The pyrolysis products were sent directly to the GC/MS in a stream of helium. Direct coupling prevents the loss of volatile compounds or the possible degradation of the pyrolysis products. The GC separations were conducted in a fused silica, capillary column (BPX 5 (SGE), 5\% Phenyl siloxane, $30 \mathrm{~m}$ length, $0.25 \mathrm{~mm}$ i.d. $(0.25 \mu \mathrm{m}$ film thickness), and helium 5.5 (Messer), 99,9995\% purity as carrier gas. The injector was set to $250{ }^{\circ} \mathrm{C}$ with a split of 100/1. The column temperature was programmed from $60^{\circ} \mathrm{C}$ to $300^{\circ} \mathrm{C}$ at $5^{\circ} \mathrm{C} \mathrm{min}^{-1}$ and held at $300^{\circ} \mathrm{C}$ for $15 \mathrm{~min}$. The ionization was produced by electron impact $(70 \mathrm{eV})$, the data were recorded in full scan mode, the source temperature was $220^{\circ} \mathrm{C}$, and the transfer line was set to $280{ }^{\circ} \mathrm{C}$. The pyrolysis or thermochemolysis products were identified on the basis of their GC retention times, and by comparison of their mass spectra with analytical standards (phenol and toluene from Sigma-Aldrich; aliphatic hydrocarbon kit, fatty acid methyl esters standards and bacterial fatty acids from Supelco) and library data (NIST). Thermochemolysis was done using tetramethyl ammonium hydroxide (TMAH) as alkylating agent. $0.5 \mathrm{mg}$ of sample was mixed with $5 \mu \mathrm{L}$ of TMAH methanolic solution $50 / 50(\mathrm{v} / \mathrm{v})$ in methanol and then placed in an inox cup in the sampler. The analysis was then conducted as for pyrolysis.

\section{Results}

\section{Stratigraphy and Mineralogy}

\section{La Fage Cave}

Four stratigraphic units were distinguished above the oolitic limestone. These are, from top to bottom (Fig. 3):

1. Unit 1 - Crudely bedded, brownish black (7,5YR 2/2), $20 \mathrm{~cm}$ thick, recent guano. It is characterized in thin section by tangled, organic debris (Fig. 4a), among which some insect fragments can be identified. Clay nodules and quartz grains indicate weak, detrital inputs during guano deposition. Despite its young age, this level contains a limestone fragment partially replaced by hydroxylapatite (Fig. 4b). Small radial aggregates of needle-shaped crystals are visible (Figs. 4c and 4d), and may correspond to the newberyite identified by X-ray 


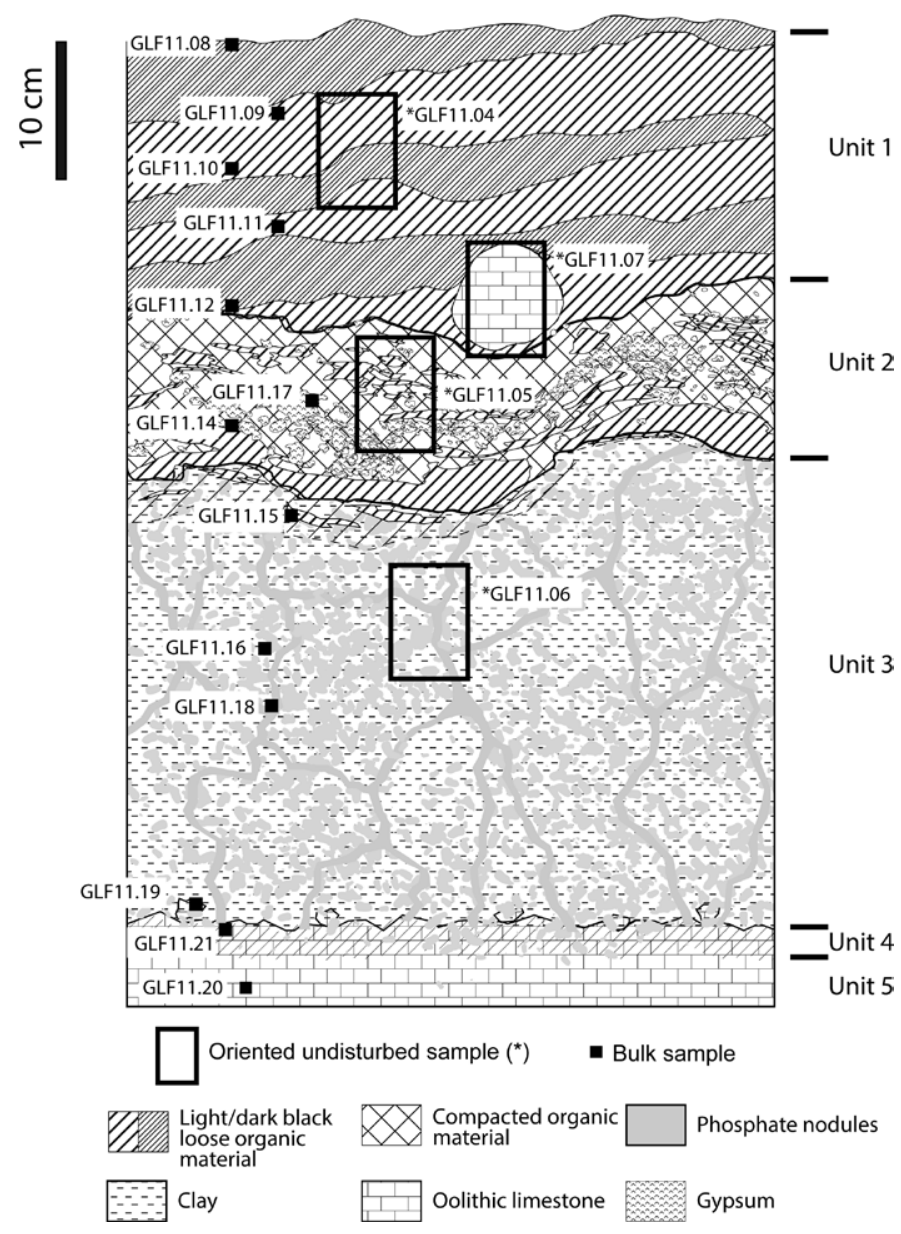

Figure 3. Stratigraphy of the guano mound in La Fage Cave and sample locations.
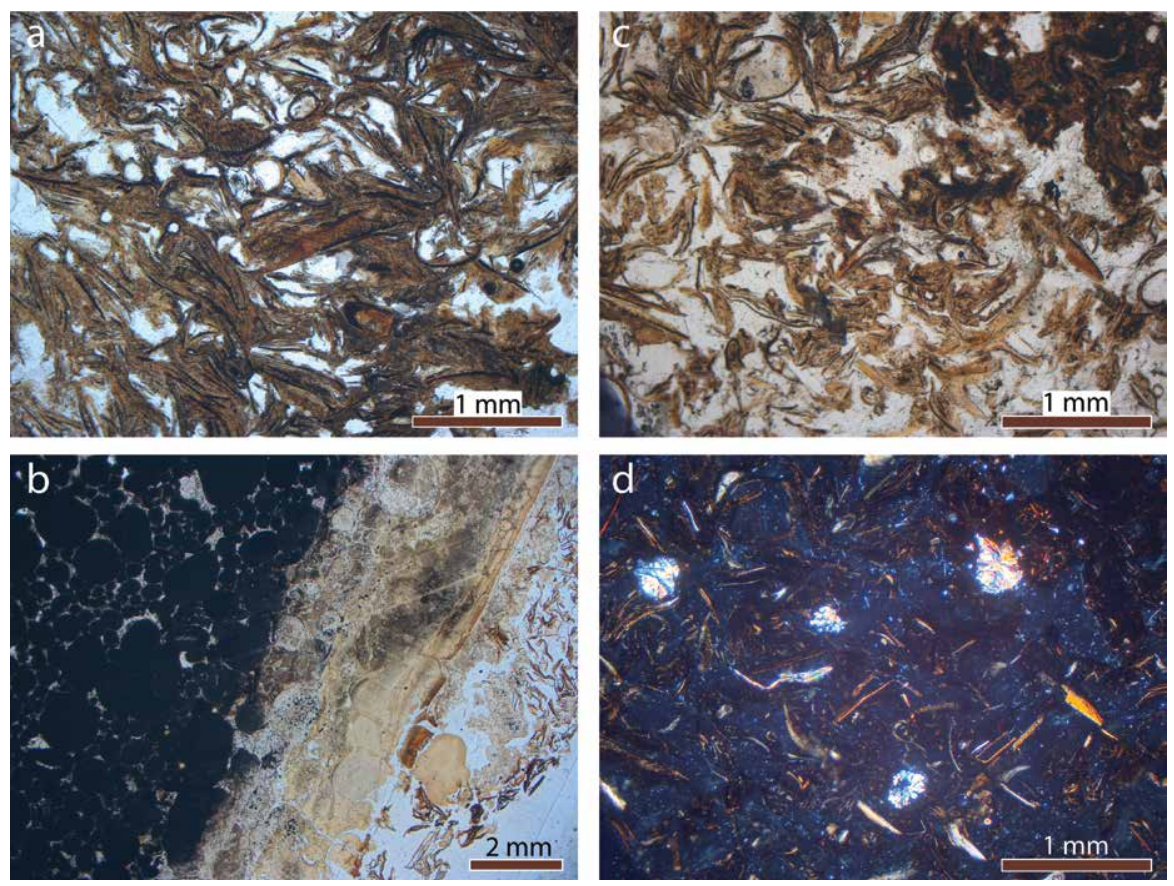

Figure 4. Microphotographs of La Fage Cave unit 1 : (a) Tangled organic debris, mainly insect fragments PPL; (b) Oolitic limestone (left) fragment partially pseudomorphosed by hydroxylapatite (right), PPL; (c) Phosphate spherulites scattered in organic debris, PPL; (d) Idem, XPL. diffraction (Fig. 6a and Table 1). The dominant mineral in this unit is brushite, even if the highly amorphous, organic content of the sample (Table 2) prevented us from satisfying Rietveld quantification. The low mineral content makes it difficult to measure the major light elements such as silicon $(\mathrm{Si})$ or phosphorus $(\mathrm{P})$, but potassium $(\mathrm{K})$ (and rubidium $(\mathrm{Rb})$ as a substitute) from feldspar or clay is detected, as is iron (Fe) (Table 3). The main trace elements are copper $(\mathrm{Cu})$ and zinc (Zn), with exceptionally high concentrations, several hundreds and thousands of $\mu \mathrm{g} / \mathrm{g}$ respectively.

2. Unit $2-10 \mathrm{~cm}$ thick, organic level with discontinuous horizontal bedding, indicated by alternating brownish black (10YR 2/2) and pale yellow (2,5Y 8/4), nodular soft beds. Thin section observation reveals that this level is composed of an organic matrix with some debris still recognizable (Fig. 6a) and authigenic minerals. The neoformed minerals are either microcrystalline phosphate grains forming homogeneous areas, or rhombic, larger crystals (Fig. 6b). Gypsum is the main mineralogical phase present in this level (Fig. 5b, Table 2), which is consistent with the high sulfur (S) content measured by combustion (Table 3). Higher guano mineralization, as indicated by the decrease in TOC, allows more elements to be identified by ED-XRF (Table 3). The contents in $\mathrm{Cu}$ and $\mathrm{Zn}$ remain markedly high.

3. Unit $3-30 \mathrm{~cm}$ thick, strong brown (7,5YR 5/8) massive clay. The desiccation cracks are filled with pale yellow $(2,5 Y$ 8/4) masses of authigenic minerals. Isolated nodules are also visible within the clay. In thin section, the fillings are formed by coalescent, micro-

crystalline phosphate nodules. X-ray diffraction allows identification of taranakite as the principal component (Fig. 5c and Table 2). Accordingly, geochemical data show high $P$ and $\mathrm{K}$ contents. Trace elements typically associated with clay are also in higher amounts at the top part of the unit, where kaolinite is the most abundant mineral. $\mathrm{Cu}$ and $\mathrm{Zn}$ concentrations decrease in this unit.

4. Unit $4-A$ yellow crust formed by pseudomorphic replacement of calcite by phosphate, developed at the top of the limestone. It preserved the limestone microstructure (as for the altered limestone fragment in Unit 1 , Fig. $4 \mathrm{~b}$ ) and is mainly composed of hydroxylapatite and taranakite (Fig. $5 d$ and Table 2). ED-XRF data show higher calcium $(\mathrm{Ca}$, as a constituent of hydroxylapatite) content than in Unit 3. Cu and especially $\mathrm{Zn}$ are present in notably high proportions (Table 3) for this phosphate crust. 
Table 1. List of the minerals identified by X-ray diffraction.

\begin{tabular}{|c|c|c|c|}
\hline Group & Mineral & Abbr.a & Chemical formulae \\
\hline \multicolumn{4}{|c|}{ Carbonates } \\
\hline & Calcite & Cal & $\mathrm{CaCO}_{3}$ \\
\hline \multicolumn{4}{|l|}{ Sulfates } \\
\hline & Gypsum & $\mathrm{Gp}$ & $\mathrm{CaSO}_{4} \cdot 2 \mathrm{H}_{2} \mathrm{O}$ \\
\hline \multicolumn{4}{|c|}{ Phosphates } \\
\hline & Ardealite & $\mathrm{Ar}$ & $\mathrm{Ca}_{2}\left(\mathrm{PO}_{3} \mathrm{OH}\right)\left(\mathrm{SO}_{4}\right) \cdot 4 \mathrm{H}_{2} \mathrm{O}$ \\
\hline & Brushite & B & $\mathrm{Ca}\left(\mathrm{PO}_{3} \mathrm{OH}\right) \cdot 2 \mathrm{H}_{2} \mathrm{O}$ \\
\hline & Francoanellite & $\mathrm{F}$ & $\mathrm{K}_{3} \mathrm{Al}_{5}\left(\mathrm{PO}_{4}\right)_{2}\left(\mathrm{PO}_{3} \mathrm{OH}\right)_{6} \cdot 12 \mathrm{H}_{2} \mathrm{O}$ \\
\hline & Hydroxylapatite & $\mathrm{H}$ & $\mathrm{Ca}_{5}\left(\mathrm{PO}_{4}\right)_{3}(\mathrm{OH})$ \\
\hline & Monetite & M & $\mathrm{Ca}\left(\mathrm{PO}_{3} \mathrm{OH}\right)$ \\
\hline & Newberyite & $\mathrm{N}$ & $\mathrm{Mg}\left(\mathrm{PO}_{3} \mathrm{OH}\right) \cdot 3 \mathrm{H}_{2} \mathrm{O}$ \\
\hline & Taranakite & $\mathrm{T}$ & $\mathrm{K}_{3} \mathrm{Al}_{5}\left(\mathrm{PO}_{3} \mathrm{OH}\right)_{6}\left(\mathrm{PO}_{4}\right)_{2} \cdot 18 \mathrm{H}_{2} \mathrm{O}$ \\
\hline \multicolumn{4}{|l|}{ Silicates } \\
\hline & Kaolinite & $\mathrm{K} \ln$ & $\mathrm{Al}_{2} \mathrm{Si}_{2} \mathrm{O}_{5}(\mathrm{OH})_{4}$ \\
\hline & K-Feldspar & KFs & $\mathrm{K}\left(\mathrm{AISi}_{3} \mathrm{O}_{8}\right)$ \\
\hline & Albite & $\mathrm{Ab}$ & $\mathrm{Na}\left(\mathrm{AISi}_{3} \mathrm{O}_{8}\right)$ \\
\hline & Montmorillonite & Mnt & $(\mathrm{Na}, \mathrm{Ca})_{0.3}(\mathrm{Al}, \mathrm{Mg})_{2} \mathrm{Si}_{4} \mathrm{O}_{10}(\mathrm{OH})_{2} \cdot \mathrm{n}\left(\mathrm{H}_{2} \mathrm{O}\right)$ \\
\hline & Muscovite & Ms & $\mathrm{KAl}_{2}\left(\mathrm{Si}_{3} \mathrm{Al}\right) \mathrm{O}_{10}(\mathrm{OH})_{2}$ \\
\hline \multicolumn{4}{|l|}{ Oxides } \\
\hline & Quartz & Qz & $\mathrm{SiO}_{2}$ \\
\hline
\end{tabular}

${ }^{a}$ Abbr. = Abbreviation
5. Unit 5 - The bedrock sampled just below the crust reveals that it has been altered by acidic percolations. Although mainly composed of calcite, gypsum occurs in significant amounts (Table 2) and the concentration of $\mathrm{Cu}$ and $\mathrm{Zn}$ remains high.

Units 1 to 4 are weakly calcareous, despite the geological environment, with $\mathrm{pH}$ ranging between 4.6 and 5.4 (Table 3).

Rancogne Cave

From top to bottom, the sequence comprises the following units (Fig. 7):

1. Unit $1-12 \mathrm{~cm}$ thick, brownish black (7,5YR 2.5/2) layer of fresh guano, showing alternating dark and light-colored beds. This unit is mainly composed of macro debris from insect cuticles. Small lenses of microcrystalline, pale-yellow phosphates are observed in thin section (Figs. 8a and 8b), and are composed of brushite and monetite (Fig. 9a). Some centimeter-thick phosphate nodules are also visible at the base of the unit, forming crude beds. The $\mathrm{pH}$ in this organic layer is remarkably low with values close to 4.0 (Table 3).

2. Unit 2 - Massive, dark brown (7.5YR 3/3) organic layer, mainly composed of compacted organic debris, as shown by the especially high TOC content (Table 3). Close

Table 2. Mineralogy of all bulk samples (see Table 1 for abbreviations).

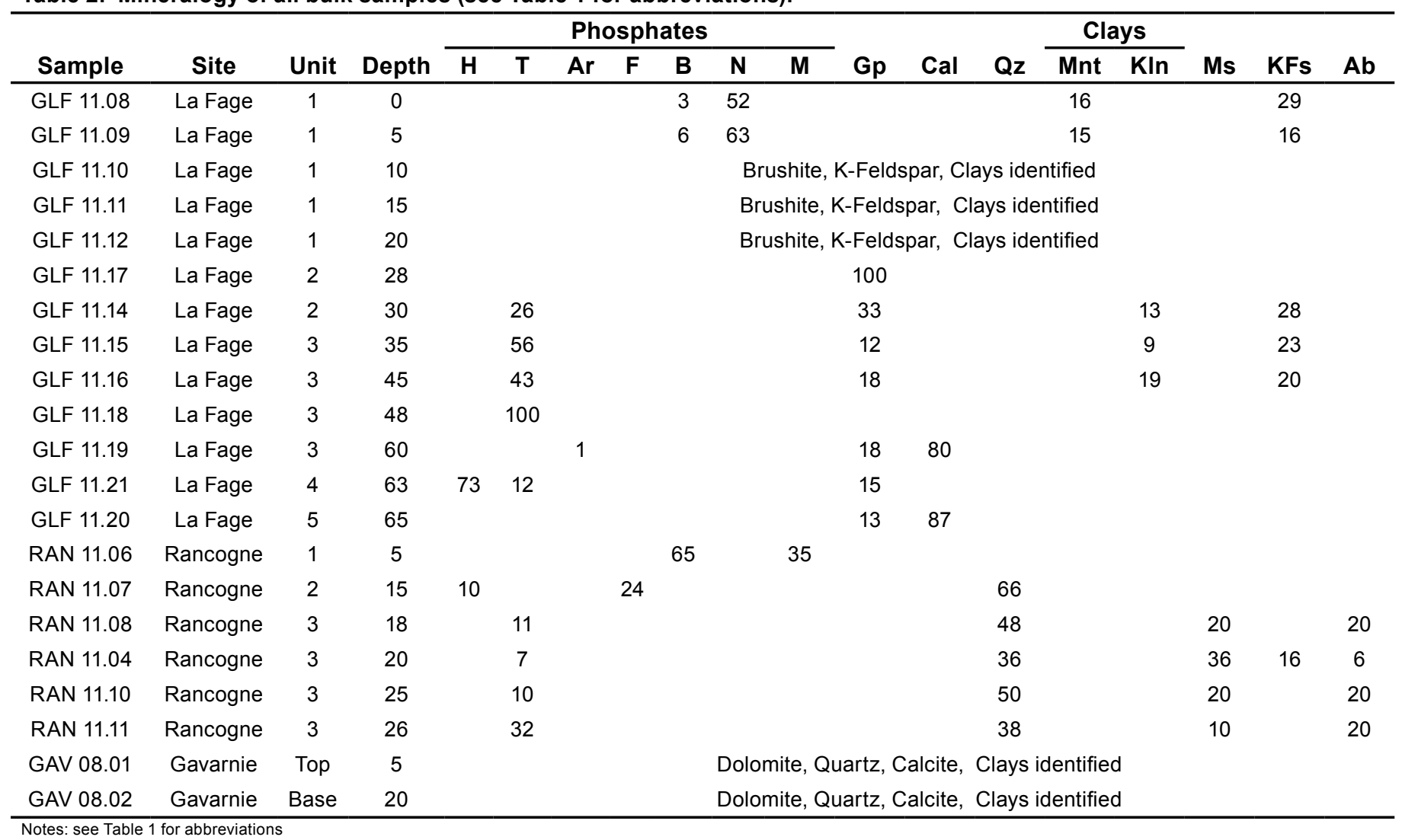




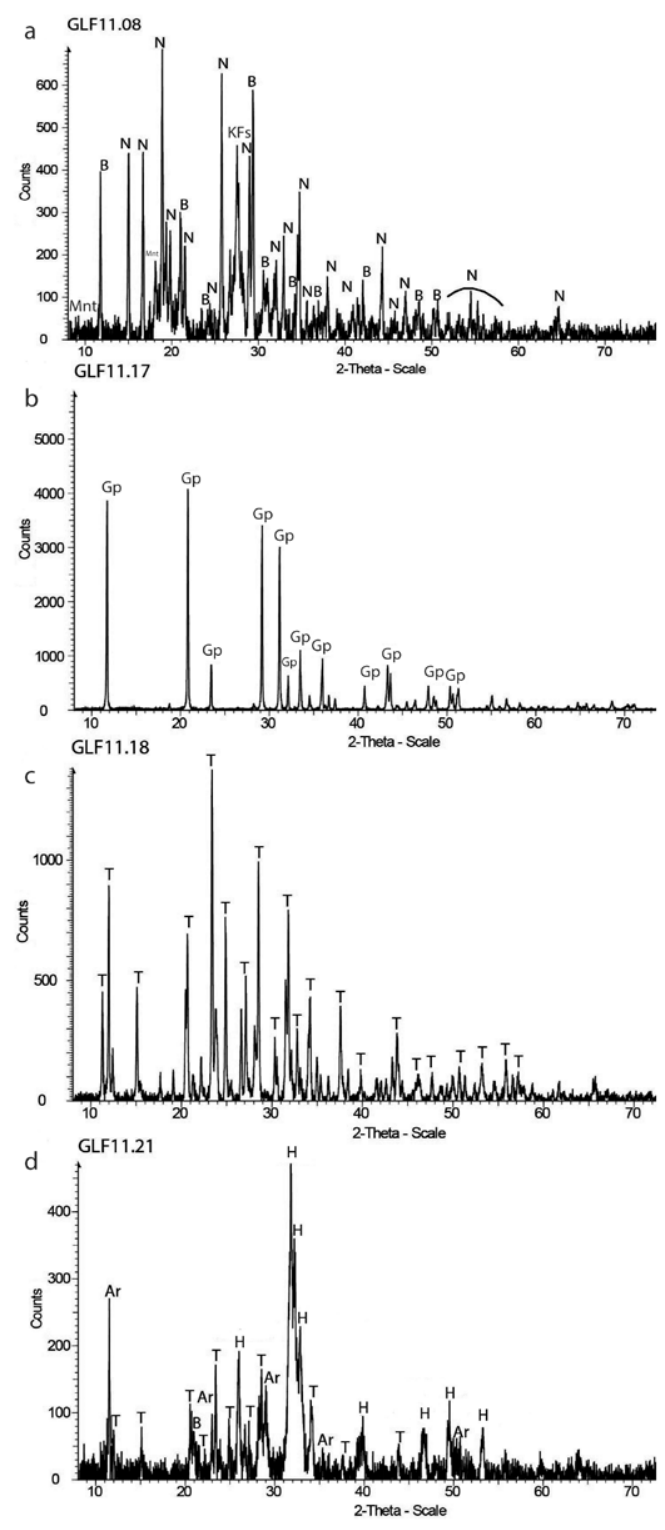

Figure 5. X-ray diffractograms of La Fage cave samples. (a) Sample GLF 11.08; (b) Sample GLF 11.17; (c) Sample GLF 11.18; (d) Sample GLF 11.21. See Table 1 for abbreviations.
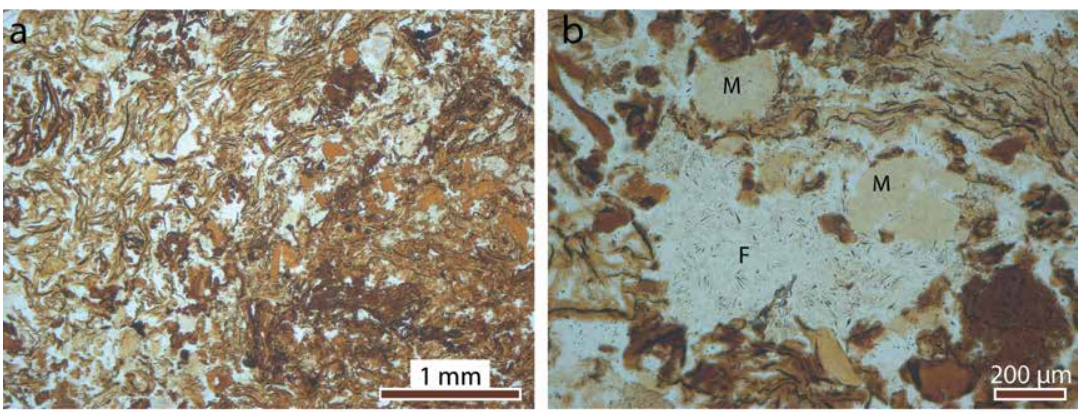

Figure 6. Microphotographs of La Fage Cave units 2 and 3: (a) Altered organic debris, PPL; (b) Microcrystalline, homogeneous phosphate nodules $(\mathrm{M})$ and fibrous and rhombic phosphate crystals (F), PPL; (c) Idem, XPL.

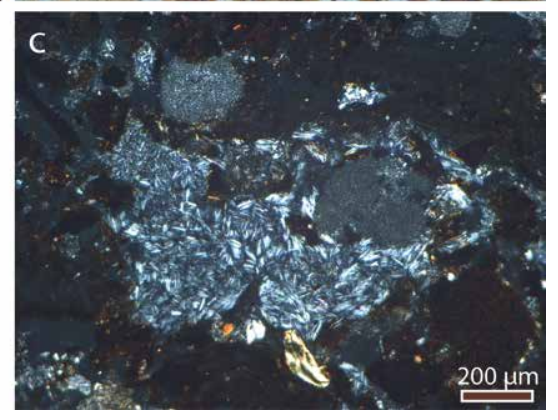

to the substratum, homogeneous, microcrystalline phosphate accumulations fill the cracks (Fig. 8c). The thickness of this unit is highly variable and ranges between $1 \mathrm{~cm}$ and $15 \mathrm{~cm}$. The minerals identified by XRD include quartz, francoanellite and hydroxylapatite (Fig. 9b). The $\mathrm{pH}$ is higher than in the overlying layer, but still remains acidic (ca. 5.2).

3. Unit 3 - Bright brown (10YR 6/6), bedded alluvial silts, which form the substrate. The amount of phosphate minerals changes significantly from one bed to another. Bed b, which is the coarsest, contains much more authigenic minerals than beds a and c (Figs. $8 \mathrm{~d}$ and $8 \mathrm{e}$ ). They are organized in small, yellowish nodules, identified as taranakite (Fig. 9c). The $\mathrm{pH}$ is particularly low with values around 5.

$\mathrm{Zn}$ concentration is high and decreases down the sequence from several thousands to a few hundreds of ppm. $\mathrm{Cu}$ is also in concentrations above normal values (i.e. typical of cave sediments). High Rb, $\mathrm{Sr}$, and $\mathrm{Zr}$ amounts reflect the detrital component of the unit.

\section{Gavarnie Cave}

The cross-section made in the mound of chough guano (Fig. 10) reveals a rather loose accumulation of organic fragments with rough bedding, marked by the alternation of centimeter-thick, dark and light beds. This alternation may be the result of seasonal variations in the activity of the bird community or in their diet. Two samples were collected in the section, and these show a total lack of authigenic minerals. Only minerals coming from the surrounding rock walls were found (Table 2). The TOC content increases three-fold from top to bottom, whereas the carbonate content decreases, indicating progressive decalcification. The $\mathrm{pH}$ remains almost neutral in both samples with a slight decrease in the deepest sample (Table 3). It is noteworthy that in this guano, $\mathrm{Cu}$ and $\mathrm{Zn}$ do not reach high concentrations and $\mathrm{P}$ is not detected in ED-XRF.

\section{Organic Matter Characterization}

\section{Pyrolysis at $600^{\circ} \mathrm{C}$}

The analysis showed important dissimilarities between bat and chough guano mounds (Table 4 and Fig. 11). The pyrolysis products of bat guano are almost exclusively composed of a series of unsaturated and saturated hydrocarbons ranging from C9 to C28 (Fig. 11a). These n-alkene/n-alkane doublets are generally produced by the pyrolysis of polymers or biopolymers made of long alkyl chains, by radical cleavage of carbon-carbon bonds (Tegelaar et al., 1989). Alkenes/alkanes doublets can also result from acid decarboxylation or alcohol dehydration, by random cleavage of carbon chains (Quénéa et al., 2006). Indeed, the probability to obtain an alkane or an alkene via the homolytic scission of 
Table 3. Chemical composition of all bulk samples.

\begin{tabular}{|c|c|c|c|c|c|c|c|c|c|c|c|c|c|c|c|c|c|c|c|c|}
\hline Sample & Site & Unit & $\begin{array}{l}\text { Depth } \\
(\mathrm{cm})\end{array}$ & $\mathrm{pH}$ & $\begin{array}{l}\text { TOC } \\
(\%)\end{array}$ & $\begin{array}{l}\text { LOI } \\
(\%)\end{array}$ & $\begin{array}{c}\mathrm{CaCO3} \\
(\%)\end{array}$ & $\begin{array}{c} \\
(\%) \\
\end{array}$ & $\begin{array}{c}\text { C total } \\
(\%)\end{array}$ & $\begin{array}{c}S i \\
(\%) \\
\end{array}$ & $\begin{array}{c}P \\
(\%)\end{array}$ & $\begin{array}{c}K \\
(\%) \\
\end{array}$ & $\begin{array}{l}\mathrm{Ca} \\
(\%) \\
\end{array}$ & $\begin{array}{c}V \\
(\mu \mathrm{g} / \mathrm{g})\end{array}$ & $\begin{array}{c}\mathrm{Fe} \\
(\mu \mathrm{g} / \mathrm{g})\end{array}$ & $\begin{array}{c}\mathrm{Cu} \\
(\mu \mathrm{g} / \mathrm{g})\end{array}$ & $\begin{array}{c}\mathrm{Zn} \\
(\mu \mathrm{g} / \mathrm{g})\end{array}$ & $\begin{array}{c}R b \\
(\mu \mathrm{g} / \mathrm{g}) \\
\end{array}$ & $\begin{array}{c}\mathrm{Sr} \\
(\mu \mathrm{g} / \mathrm{g})\end{array}$ & $\begin{array}{c}\mathrm{Zr} \\
(\mu \mathrm{g} / \mathrm{g})\end{array}$ \\
\hline GLF 11.08 & La Fage & 1 & 0 & 5.3 & 30 & 87 & 1 & 1.7 & 30 & $<$ LOD & $<$ LOD & 1.598 & 0.6996 & $<$ LOD & 0.05545 & 213 & 2548 & 11.5 & 7.3 & $<$ LOD \\
\hline GLF 11.09 & La Fage & 1 & 5 & 5.4 & 30 & 86 & 0 & 1.5 & 30 & $<$ LOD & $<$ LOD & 1.395 & 1.807 & $<$ LOD & 0.08432 & 269 & 4478 & 13.5 & 11.8 & 7.8 \\
\hline GLF 11.10 & La Fage & 1 & 10 & 4.7 & 35 & 90 & 1 & 1.3 & 35 & $<L O D$ & 3.28 & 5.309 & 1.626 & $<$ LOD & 0.3203 & 1355 & 4121 & 14.8 & 7.6 & $<L O D$ \\
\hline GLF 11.11 & La Fage & 1 & 15 & 4.8 & 37 & 92 & 1 & 1.7 & 37 & $<L O D$ & 3.95 & 4.708 & 1.71 & $<L O D$ & 0.3176 & 1419 & 3598 & 10.8 & $<$ LOD & $<$ LOD \\
\hline GLF 11.12 & La Fage & 1 & 20 & 4.8 & 38 & 93 & 0.5 & 1.7 & 38 & $<$ LOD & $<$ LOD & 0.8052 & 0.6068 & $<$ LOD & 0.0899 & 332.4 & 2309 & 10.2 & $<$ LOD & 8.4 \\
\hline GLF 11.17 & La Fage & 2 & 28 & $\cdots$ & $\cdots$ & $\cdots$ & $\cdots$ & $\cdots$ & $\cdots$ & 0.79 & $2 a$ & 0.4372 & 18.62 & $<$ LOD & 0.12 & 545.6 & 285.9 & $<$ LOD & $<$ LOD & 104.6 \\
\hline GLF 11.14 & La Fage & 2 & 30 & 4.6 & 13 & 48 & 0.5 & 3.3 & 13 & 4.61 & 5.19 & 2.767 & 2.424 & $<$ LOD & 2.618 & 1632 & 1717 & 41.4 & 37.6 & 118.4 \\
\hline GLF 11.15 & La Fage & 3 & 35 & 5.0 & 1 & 25 & 0 & 0.4 & 1 & 8.26 & 9.86 & 5.103 & 0.2147 & 43.9 & 4.323 & 307.5 & 605.1 & 53.8 & 42.5 & 209.7 \\
\hline GLF 11.16 & La Fage & 3 & 45 & 5.2 & 0.5 & 21 & 0 & 0.3 & 0.5 & 14.59 & 4.28 & 4.087 & 0.1936 & 91.3 & 5.526 & 299.2 & 406 & 71.6 & 73.1 & 240.6 \\
\hline GLF 11.18 & La Fage & 3 & 48 & $\cdots$ & $\cdots$ & $\cdots$ & $\cdots$ & $\cdots$ & $\cdots$ & 2.04 & 14.7 & 6.872 & 0.2138 & $<$ LOD & 2.099 & 217.7 & 160.8 & 23 & $<$ LOD & 140.1 \\
\hline GLF 11.19 & La Fage & 3 & 60 & $\cdots$ & $\cdots$ & $\cdots$ & & & $\cdots$ & 4 & $6 a$ & 0.7439 & 63.86 & $<$ LOD & 0.6559 & 720 & 3603 & 15.6 & 43.2 & 397.2 \\
\hline GLF 11.21 & La Fage & 4 & 63 & 5.0 & $\cdots$ & $\cdots$ & $\cdots$ & $\cdots$ & $\cdots$ & 2.5 & 9.696 & 1.487 & 22.53 & 52.2 & 0.5816 & 436 & 6427 & 11 & 44.2 & 196.9 \\
\hline GLF 11.20 & La Fage & 5 & 65 & $\cdots$ & $\cdots$ & $\cdots$ & $\cdots$ & $\cdots$ & $\cdots$ & 3.96 & $6 a$ & 0.6657 & 86.56 & $<$ LOD & 0.1741 & 1026 & 4456 & $<L O D$ & 152.9 & 506.7 \\
\hline RAN 11.06 & Rancogne & 1 & 5 & 4.0 & 25 & 72 & 1 & 1.6 & 25 & $<$ LOD & $<$ LOD & 0.8651 & 4.784 & $<$ LOD & 0.1322 & 315.8 & 3386 & 9.8 & 9.5 & 8.4 \\
\hline RAN 11.07 & Rancogne & 2 & 15 & 5.2 & 34 & 92 & 0.5 & 1.0 & 34 & 1.8 & $<$ LOD & 1.175 & 2.738 & LOD & 0.8305 & 1318 & 1039 & 49.1 & 79.7 & 218.9 \\
\hline RAN 11.08 & Rancogne & 3 & 18 & 5.0 & 1 & 9 & 0 & 0.1 & 1.5 & 23.18 & $<$ LOD & 2.881 & 0.6522 & 45.2 & 3.162 & 213.1 & 400.6 & 169.1 & 94.1 & 425.8 \\
\hline RAN 11.04 & Rancogne & 3 & 20 & 5.0 & 1 & 5 & 0 & 0.1 & 1 & 20.95 & $<$ LOD & 2.868 & 0.4632 & 74.7 & 5.044 & 160.3 & 553.7 & 186.8 & 59.4 & 391.8 \\
\hline RAN 11.10 & Rancogne & 3 & 25 & 5.3 & 2 & 12 & 0 & 0.2 & 2 & 23.24 & $<$ LOD & 2.904 & 0.7394 & $<$ LOD & 3.218 & 234.7 & 471.7 & 158.9 & 85.1 & 414.1 \\
\hline RAN 11.11 & Rancogne & 3 & 26 & $\cdots$ & $\cdots$ & $\cdots$ & $\cdots$ & $\cdots$ & $\cdots$ & 18.02 & 2.88 & 3.741 & 0.5194 & 28.1 & 2.454 & 235.3 & 295.9 & 140.6 & 73.5 & 339.1 \\
\hline GAV 08.01 & Gavarnie & Top & 5 & 7.0 & 10 & 60 & 8 & 0.2 & 11 & 5.38 & $<$ LOD & 0.5335 & 10.75 & $<$ LOD & 0.8309 & 51.6 & 113 & 30.5 & 91 & 90.6 \\
\hline GAV 08.02 & Gavarnie & Base & 20 & 6.8 & 31 & 87 & 1 & 0.8 & 32 & 2.46 & $<$ LOD & 0.3695 & 7.197 & $<$ LOD & 0.7004 & 111.8 & 133.9 & 23.1 & 91.8 & 78.4 \\
\hline
\end{tabular}

Notes: TOC = Total Organic Carbon, LOI = Loss On Ignition, $<$ LOD $=$ under the limit of detection
a Values strongly influenced by Ca escape lines because of interaction with the silicon detector as observed on the spectra. The expected values are probably much lower.

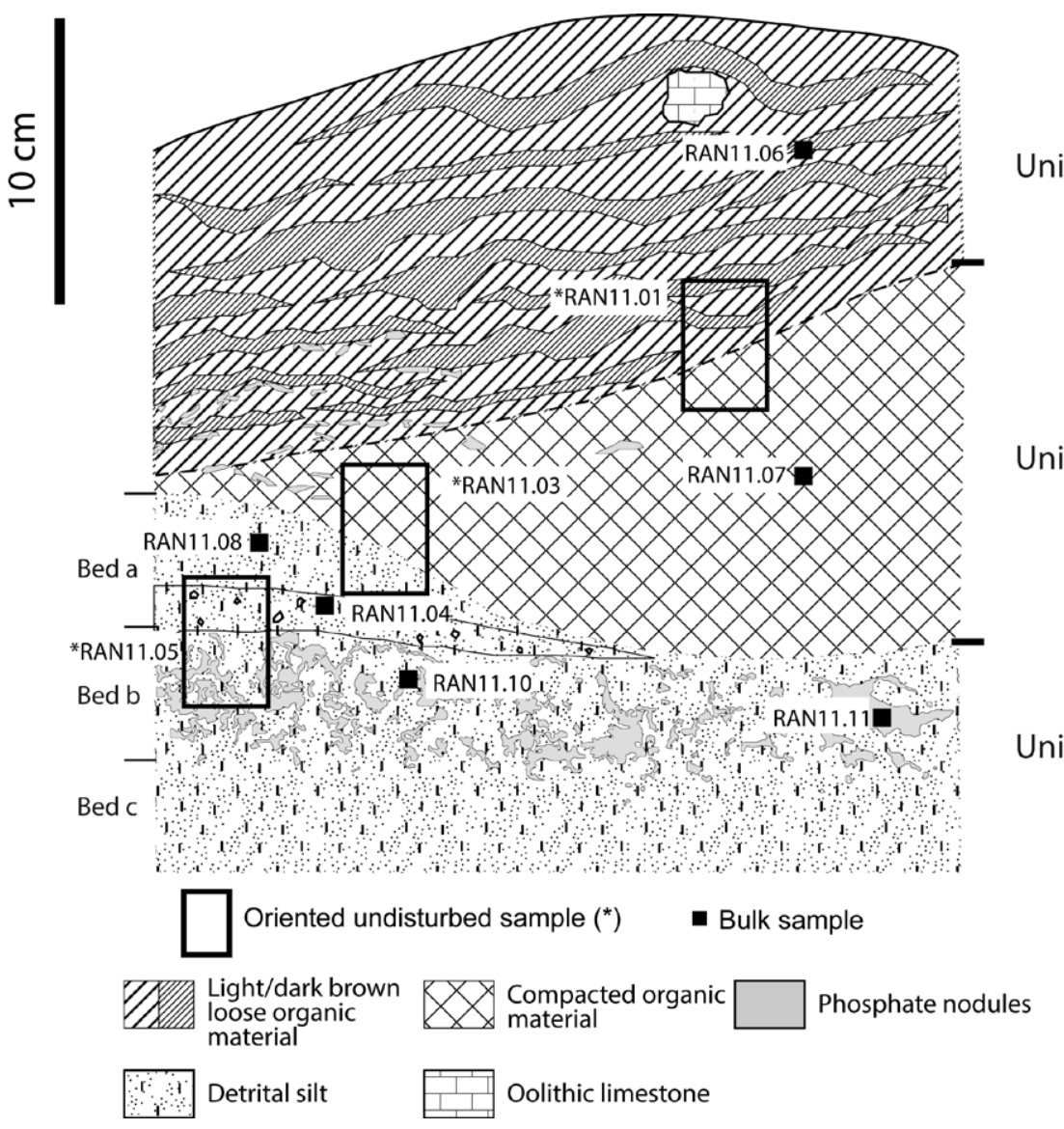

Figure 7. Stratigraphy of the guano mound in Rancogne Cave and sample locations. an alkyl chain is the same, thus resulting in a doublet on the chromatogram. This hypothesis is supported by the total lack of such alkane/alkene series within the products of pyrolysis at lower temperature $\left(200^{\circ} \mathrm{C}\right)$. This demonstrates indeed that these doublets are not present on the sample in natural state, but are only observed when created by pyrolysis at 600 ${ }^{\circ} \mathrm{C}$. The short-chained alkanes/alkenes, coming from the cleavage of long chains, may indicate the importance of insect cuticles. Indeed, hydrocarbons are important components of the cuticular lipids of many insects. These lipids are essentially composed of long, odd numbered, carbon chain (generally from C21 to C33) hydrocarbons (Blomquist, 2010) and Unit 3 branched alkanes (Kolattukudy, 1976). The aliphatic biopolymer, characterized by the alkane/alkene doublets, can be produced by a diagenetic polymerization of cuticular waxes and internal body lipids (Stankiewicz et al., 1998).

In mass spectrometry, the $\mathrm{m} / \mathrm{z} 57$ fragment is diagnostic of alkyl chains. This molecular ion is used to selectively detect alkanes from a complex sample. 

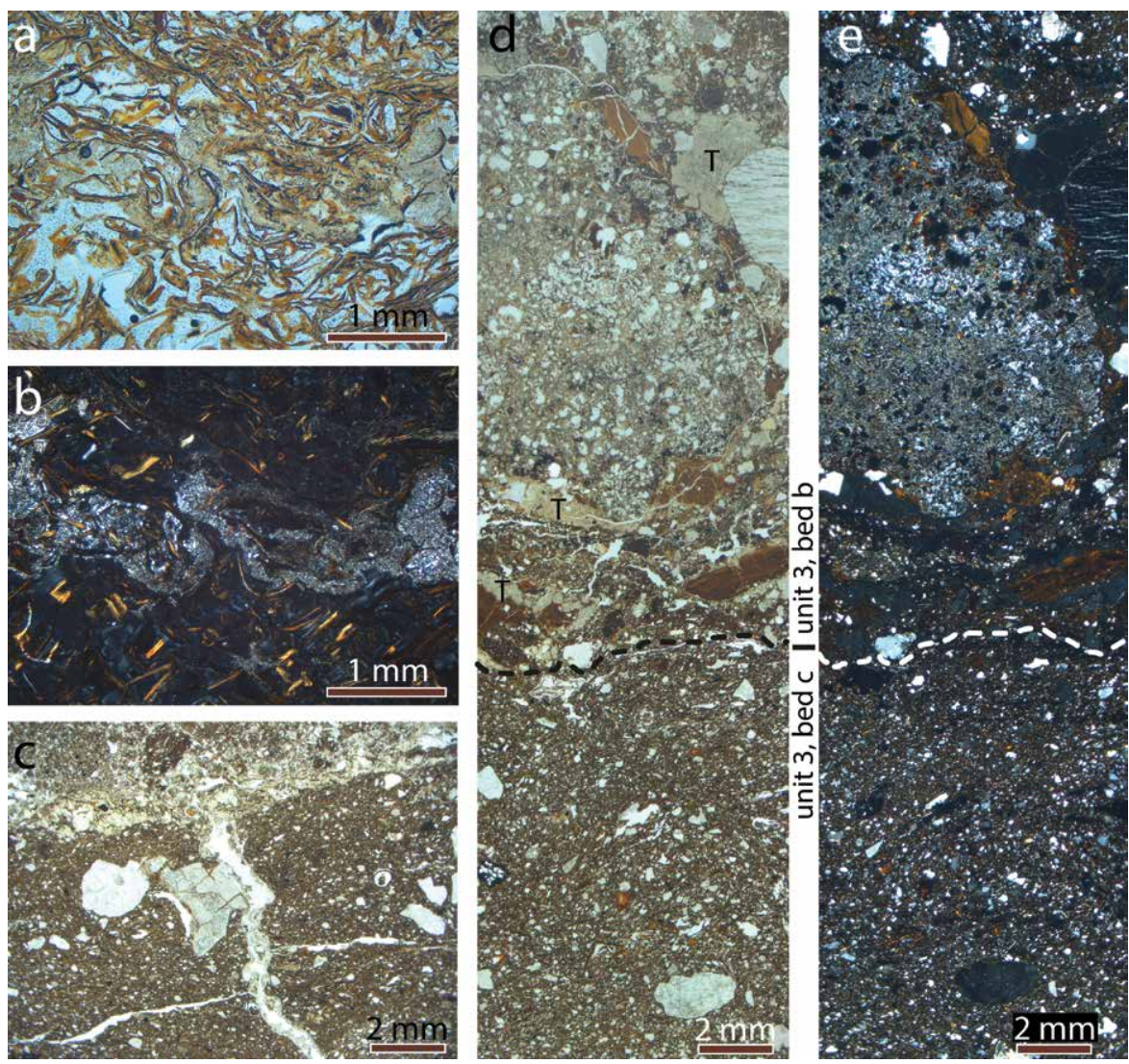

The comparison between the total ion current (Fig. 11a), representing all the detected compounds, and the $\mathrm{m} / \mathrm{z} 57$ ion extract (Fig. 11b) clearly shows that hydrocarbons are the main products of the pyrolysis at $600^{\circ} \mathrm{C}$. The 57 ion extracts from the two samples reflect notably similar distributions in alkanes.

The pyrolysis of chough guano is far more complex (Fig. 11c). The peaks marked with $\mathrm{L}, \mathrm{C}, \mathrm{N}$ correspond, respectively, to pyrolysis products derived from lignin, cellulose and proteins/chitin. Some alkenes (marked n:1) can be distinguished as trace compounds.

Thermochemolysis (TMAH pyrolysis $600^{\circ} \mathrm{C}$ )

Pyrolysis at $600{ }^{\circ} \mathrm{C}$ in the presence of tetramethylammonium hydroxide, as alkylating reagent, makes it possible for the detection of polar compounds such as fatty acids, that tend to be degraded by classical pyrolysis (del Río and Hatcher, 1998) cuticles and a suberin. Thermochemolysis is complementary to pyrolysis, and improves the detection of fatty acids, whereas the hydrocarbons are minored.

Fatty acids can be selectively detected in mass spectrometry, using the $\mathrm{m} / \mathrm{z} 74$ fragment as a diagnostic ion, resulting from the classical McLafferty's rearrangement (McLafferty, 1959). The comparison of the total ion current (TIC), obtained by thermochemolysis of bat guano (Fig. 12a) and the $\mathrm{m} / \mathrm{z} 74$ ion extract (Fig. 12b), shows that fatty acids are the major constituents obtained by thermochemolysis. They are mainly composed of long, even chained compounds usually interpreted to be of higher plant origin (Kolattukudy, 1976). However, lignin is almost absent from the pyrolysis analysis and long-chain fatty acids have also been observed in fungi (Rezanka and Mareš, 1987; Řezanka, 1989).

The distribution of fatty acids in chough guano is displaced toward the short-chained compounds (Fig. 13). Unlike bat guano, fatty acids are not the
Figure 8. Microphotographs of Rancogne Cave samples: (a) Microcrystalline phosphate lens in organic debris, PPL; (b) Idem, XPL; (c) Microcrystalline and homogeneous phosphate lens partially filling a crack in the silty sediment, PPL; (d) Yellowish phosphate nodule of taranakite $(T)$ and its distribution in the beds $\mathrm{b}$ and $\mathrm{c}$, unit 3 , PPL; (e) Idem, XPL.

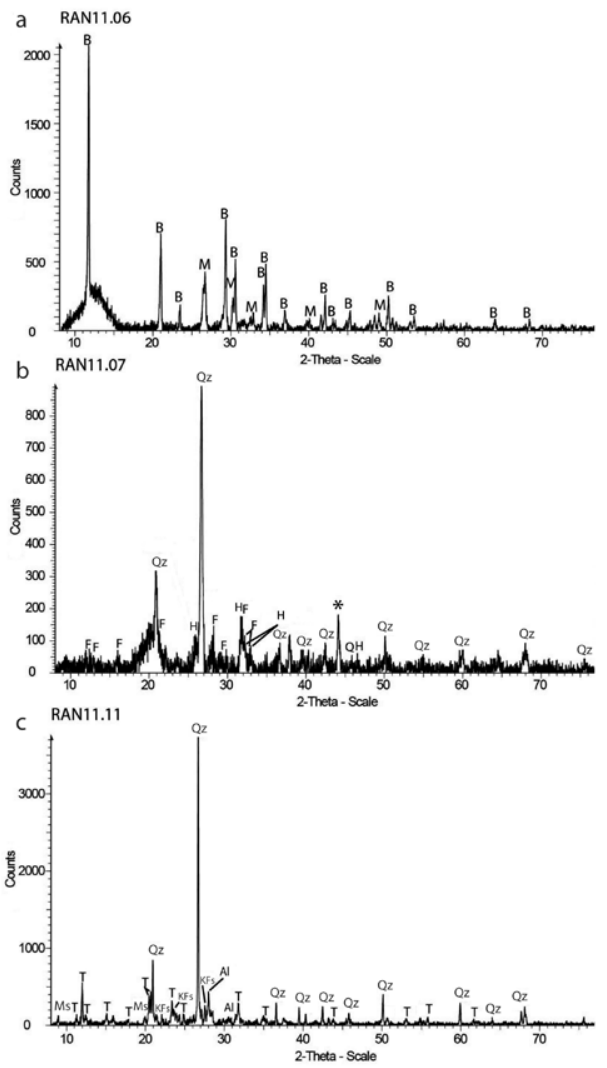

Figure 9. X-ray diffractograms of Rancogne cave samples: (a) Sample RAN 11.06; (b) Sample RAN 11.07; (c) Sample RAN 11.11. See Table 1 for abbreviations. (*) is for the diffraction peak of sample holder that diffracted with organic-rich sample. 


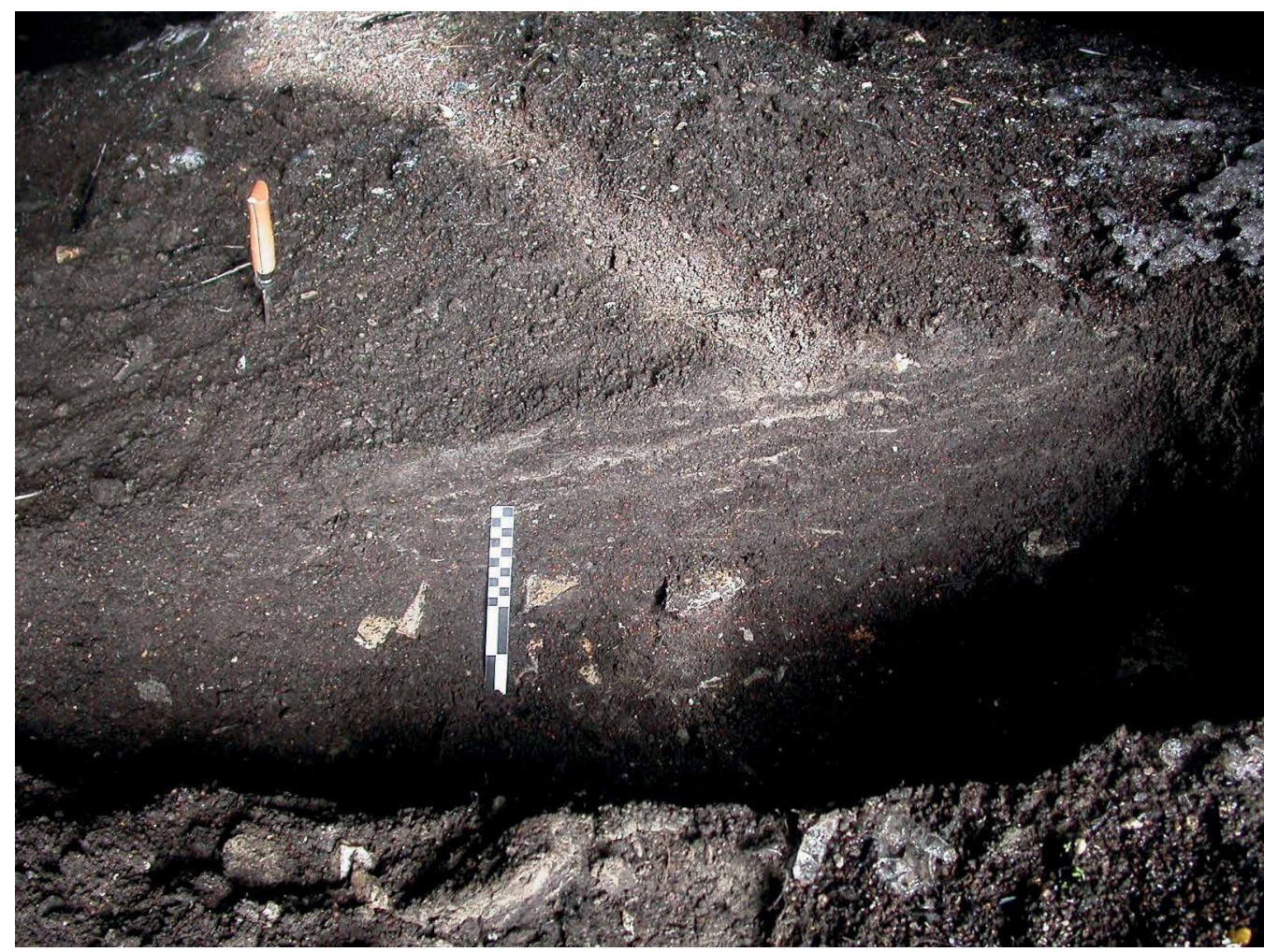

Figure 10. Gavarnie Cave test-pit. The scale bar is $20 \mathrm{~cm}$ long. main constituents and other compounds (hydroxyl acids, diacids) are also present (Table 5).

\section{Discussion}

The La Fage Cave section allows observation and study of a complete sequence documenting the evolution of insectivorous bat guano in a calcareous context, under humid, temperate climate (Fig. 14).

The first stage of guano decomposition is accompanied by the formation of newberyite, a mineral present only in the top part of the accumulation. This magnesium phosphate may form directly from phosphate solutions. Magnesium is naturally present in small amounts in guano (Perrenoud, 1993), but has probably been brought mainly by water flowing through dolomitized limestone (Martini and Kavalieris, 1976), which crops out in the upstream part of the karst system (Lefavrais-Raymond et al., 1976). According to Hutchinson (1950) and Hill and Forti (1997), newberyite may have struvite (an unstable magnesium and ammonium phosphate) as a precursor, and may result from its transformation by loss of soluble ammonia, and by dehydration (Boistelle et al., 1983). This mineral, identified in the Grotte $\mathrm{XVI}$ sediments, is proposed by Karkanas et al. (2002) as an evidence for bat guano origin of phosphate-rich sediments. The mineral crystallized in recent guano into small, scattered and radial nodules, only visible under the microscope.

Several centimeters below the newberyite-rich layer in Unit 1, the only phosphate mineral identified is brushite. This phosphate, especially common in caves (Fiore and Laviano, 1991; Hill and Forti, 1997; Marincea et al., 2004) forms from solutions provided by the decomposition of guano in a humid environment and under acidic conditions ( $\mathrm{pH}$ less than 6) (Hill and Forti, 1997).

In Unit 2, which corresponds to older and more degraded guano, brushite disappears and gypsum becomes largely dominant, in association with taranakite, an aluminum phosphate. Organic matter degradation increases and, as a consequence, the sediment becomes more acidic because of bacteria-induced production of sulfuric acid (Li et al., 2008; Paul, 2007). The origin of the sulfur used by these bacteria can be from bat guano (Hosono et al., 2006). The presence of sulfuric acid seems to be the main factor involved in gypsum formation (Rinaudo and Abbona, 1988; Hill and Forti, 1997; Shahack-Gross et al., 2004; Dumitraş et al., 2008; Engel et al., 2004). In the La Fage test-pit, this is correlated with the lowest $\mathrm{pH}$ values, which are close to 4.6. The loose arrangement of the organic material allows for the authigenic minerals to form in the voids. Therefore, no signs of sediment disturbance due to crystallization were observed.

Percolation appears to be the main factor that explains the stratigraphic distribution of secondary minerals. Higher affinity of $\mathrm{SO}_{4}{ }^{2-}$ to $\mathrm{Ca}^{2+}$, when compared with $\mathrm{PO}_{4}{ }_{4}^{3-}$, results in the progressive depletion in $\mathrm{SO}_{4}{ }^{2-}$ and $\mathrm{Ca}^{2+}$ of the solutions, in the preferential precipitation of gypsum, in the upper part of the sequence (guano layers), and the presence of phosphates only in the underlying clay layer. Clay alteration, due to acidic, phosphate-rich solutions, releases $\mathrm{Al}$ and $\mathrm{K}$, leading to the crystallization of taranakite. This aluminum phosphate is frequently encountered in caves (Sakae and Sudo, 1975; Fiore and Laviano, 1991; Marincea et al., 2002; Onac and Vereş, 2003; Puşcaş et al., 2014). It is a marker of humid environment and its crystallization needs acidic solutions (Puşcaş et al., 2014). In La Fage Cave, taranakite is largely predominant in clay and forms millimeter- to centimeter-thick fillings of desiccation cracks, giving way to a network of phosphatized veins. Francoanellite, a mineral similar to taranakite with less structural water, is present in small amounts and may reflect partial drying of the deposit (Onac and Vereş, 2003). Taranakite, as other aluminum phosphates, is assumed to be stable and is part of the common mineral association usually described in archeolog- 
Table 4. Pyrolysis products and their probable origin for both guano samples.

\begin{tabular}{|c|c|c|c|}
\hline Ret.Time $^{a}$ & Bats & Chough & Origin/class of compound \\
\hline 1.993 & & Propanal & cellulose \\
\hline 2.193 & & Amino-pentanol & nitrogen containing compound \\
\hline 2.287 & & Hydrazine, butenyl- & nitrogen containing compound \\
\hline 2.363 & & Butanoic acid & \\
\hline 3.553 & & 1H-Pyrrole, methyl- & nitrogen containing compound \\
\hline 3.743 & & Pyridine & nitrogen containing compound \\
\hline 4.007 & & Toluene & lignin \\
\hline 4.493 & & Hydroxymethyl-furane & cellulose \\
\hline 4.790 & & Furfural & cellulose \\
\hline 5.157 & & Furfural & cellulose \\
\hline 5.427 & Methyl pyrrole & Methyl pyrrole & nitrogen containing compound \\
\hline 6.5 & Nonene (C9:1) & & alkene \\
\hline 6.59 & styrene & & lignin \\
\hline 6.75 & Nonane (C9) & & alkane \\
\hline 7.413 & & Cyclopentanedione & cellulose \\
\hline 8.443 & & methyl furancarboxaldehyde & cellulose \\
\hline 8.990 & Phenol & Phenol & lignin \\
\hline 9.297 & Decene (C10 :1) & Decene & alkene \\
\hline 9.5 & Decane (C10) & & alkane \\
\hline 10.357 & & Methyl cyclopentanedione & cellulose \\
\hline 11.0 & indene & & nitrogen containing compound \\
\hline 11.230 & & 2-methyl- Phenol & lignin \\
\hline 11.890 & & 4-methyl- Phenol & lignin \\
\hline 12.360 & Undecene (C11:1) & Undecene & alkene \\
\hline 12.6 & Undecane (C11) & & alkane \\
\hline 15.440 & & Menthol, O-isobutenyryl- & lignin \\
\hline 15.7 & Dodecane (C12) & & alkane \\
\hline 16.343 & & dihydro Benzofuran & lignin \\
\hline \multirow[t]{3}{*}{18.587} & & Indole & nitrogen containing compound \\
\hline & Dodecanal (Ald C12) & & aldehyde \\
\hline & Tridecene $(\mathrm{C} 13: 1)$ & & alkene \\
\hline \multirow[t]{4}{*}{19.057} & & Hydroxy-methylacetophenone & lignin \\
\hline & tetradecene $(\mathrm{C} 14: 1)$ & & alkene \\
\hline & Dodecanone (ket C12) & & ketone \\
\hline & Tetradecane (C14) & & alkane \\
\hline 21.237 & & 1H-Indole, methyl- & nitrogen containing compound \\
\hline 22.863 & & Phenol, methoxy-(propenyl) & lignin \\
\hline \multirow[t]{16}{*}{23.917} & Pentadecene (C15:1) & Pentadecene & alkene \\
\hline & Pentadecanal (Ald C15) & & aldehyde \\
\hline & Hexadecene (C16:1) & & alkene \\
\hline & Methyl nonenone & & ketone \\
\hline & heptadecene (C17 :1) & & alkene \\
\hline & Heptadecane (C17) & & alkane \\
\hline & Octadecene (C18:1) & & alkene \\
\hline & Nonadecene (C19:1) & & alkene \\
\hline & Eicosene (C20 :1) & & alkene \\
\hline & Uncosene (C21:1) & & Alkene \\
\hline & Docosene (C22 :1) & & Alkene \\
\hline & Tricosene (C23:1) & & Alkene \\
\hline & Tetracosene (C24:1) & & Alkene \\
\hline & Pentacosene (C25:1) & & Alkene \\
\hline & Hexacosene (C26:1) & & Alkene \\
\hline & Octcosene (C28:1) & & alkene \\
\hline 53.473 & & Hentriacontane (C31) & alkane \\
\hline 53.907 & & Stigmastan-3,5-diene & steroide \\
\hline 57.337 & & pentatriacontane (C35) & alcane \\
\hline
\end{tabular}

${ }^{a}$ Ret. Time $=$ retention time on the chromatogram. 

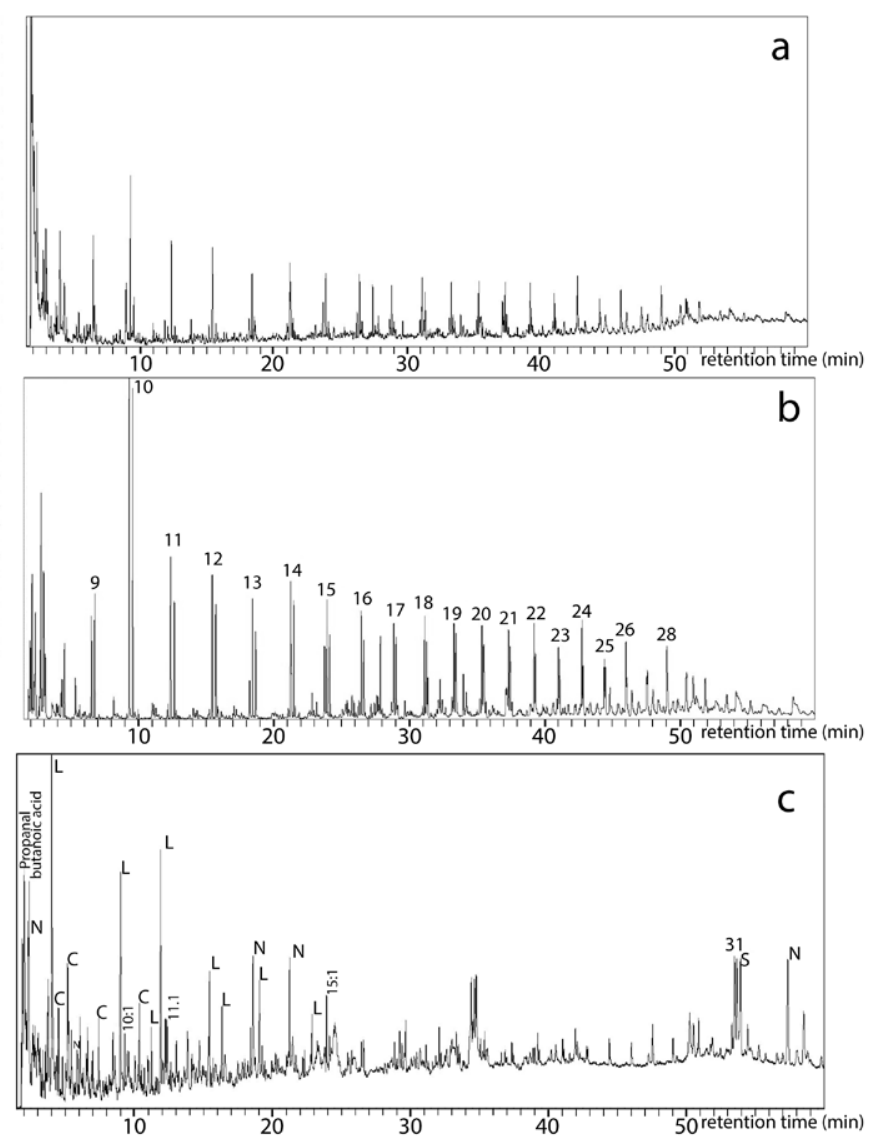

Figure 11. Pyrolysis products obtained at $600{ }^{\circ} \mathrm{C}$ (Py-GC/MS). (a) Total ion current of bat guano; (b) lon extract ( $\mathrm{m} / \mathrm{z} 57$ ) of bat guano; (c) Total ion current of chough guano. $\mathrm{L}=$ lignin, $\mathrm{C}=$ cellulose, $\mathrm{N}=$ nitrogen containing compounds, $\mathrm{n}=$ alkane with $\mathrm{n}$ carbon atoms.
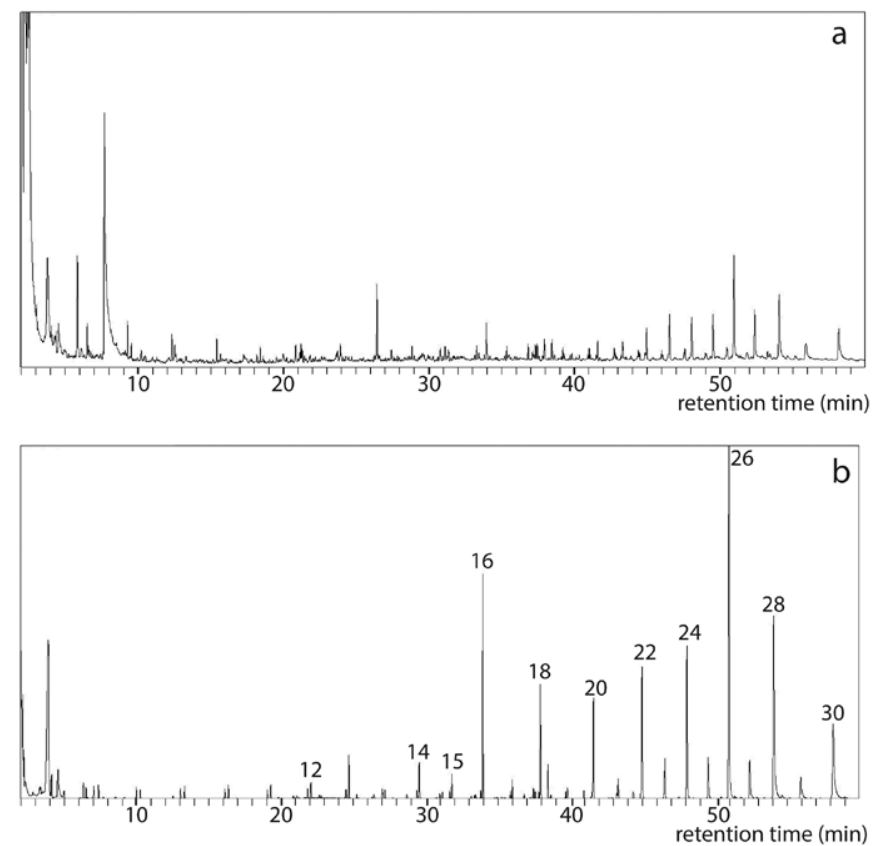

Figure 12. Thermochemolysis (TMAH) products of bat guano. (a) Total ion current (b) lon extract (m/z 74).
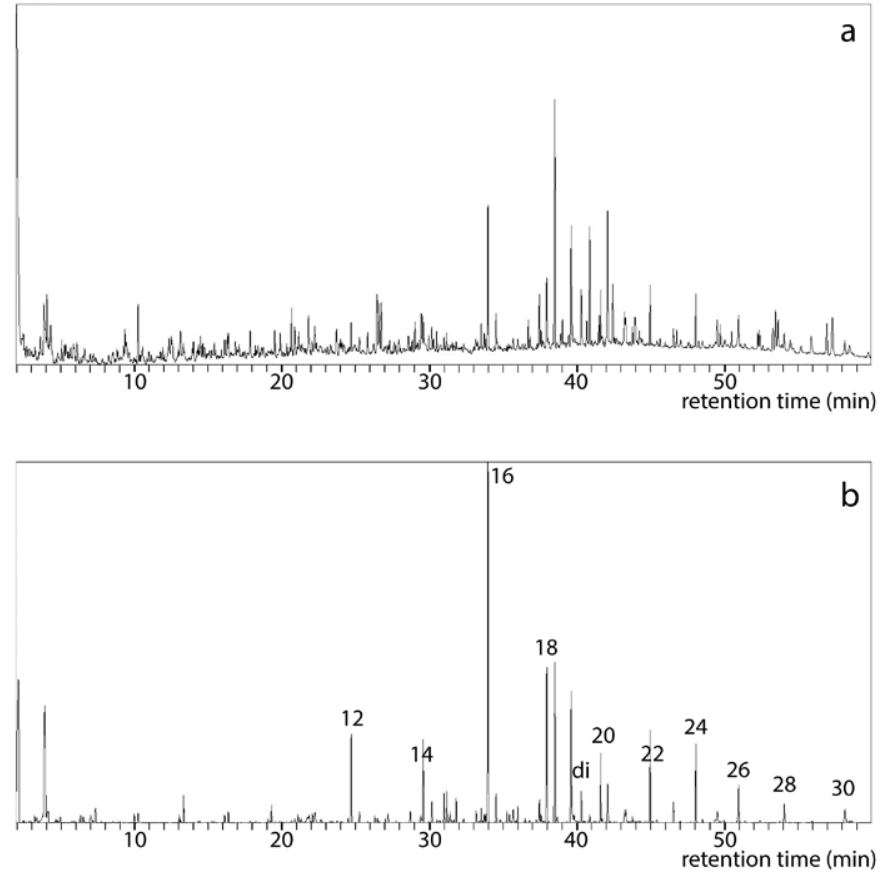

Figure 13. Thermochemolysis (TMAH) products of chough guano. (a) Total ion current; (b) lon extract ( $\mathrm{m} / \mathrm{z} 74)$.

ical contexts, along with hydroxylapatite, notably in the Levant and Greece (Hill and Forti, 1997; Karkanas et al., 2000; Weiner et al., 2002). However, it has to be noted that taranakite is absent, to our knowledge, in all Pleistocene sites investigated in southwest France (Bertran, 1999; Karkanas et al., 2002; Ajas et al., 2013). Because of the accumulation of abundant limestone debris released by frost wedging of the walls during the glacial periods, basic conditions probably prevailed most of the time in cave sediments. This process is tentatively assumed to be the main factor involved in the poor preservation of taranakite.

Deeper into the sequence, an alteration crust formed at the top of the limestone by pseudomorphic replacement of calcite by hydroxylapatite. Limestone dissolution by acidic solutions released $\mathrm{Ca}^{2+}$ ions that favored the formation of hydroxylapatite. Such an evolution is documented in numerous caves (Hutchinson, 1950; Goldberg and Nathan, 1975; Martini and Kavalieris, 1976; Courty et al., 1989; Perrenoud, 1993; Hill and Forti, 1997; Ajas et al., 2013; Wurster et al., 2015). Thinner crusts with ardealite, brushite and hydroxylapatite developed also around limestone blocks scattered in Unit 3. This association has already been described in the archeological sites of Kebara and Tabun in the Near East by Goldberg and Nathan (1975). Karkanas et al. (2000) and Shahack-Gross et al. (2004) suggested that this association reflects a chain of mineral reactions, which are strongly dependent on the geochemical micro-environments around the blocks.

In Rancogne Cave (Fig. 15), the transformation of guano is disturbed by river floods. Units 1 (fresh guano), 2 (old guano) and 3 (alluvial silts) are separated by unconformi- 
Table 5. Thermochemolysis products and their probable origin for both guano samples.

\begin{tabular}{|c|c|c|c|}
\hline Ret.Time $^{a}$ & Bats & Chough & Origin/class of compound \\
\hline 5.825 & Dimethyl phosphite & & phosphate \\
\hline 6.517 & Nonene (C9:1) & & hydrocarbon \\
\hline 7.767 & trimethyl phosphate & & phosphate \\
\hline 9.283 & Decene $(C 10: 1)$ & & hydrocarbon \\
\hline 9.55 & Decane $(C 10)$ & & hydrocarbon \\
\hline 10.242 & & methoxy methyl benzene & \\
\hline 12.342 & Undecene (C11:1) & & hydrocarbon \\
\hline 12.525 & methyl benzoate & & lignin \\
\hline 12.617 & Undecane (C11) & & hydrocarbon \\
\hline 15.417 & Dodecene $(\mathrm{C} 12: 1)$ & & hydrocarbon \\
\hline 15.675 & Dodecane (C12) & & hydrocarbon \\
\hline 17.8 & & methyl indole & \\
\hline 18.183 & Methyl dodecene & & hydrocarbon \\
\hline 18.392 & Tridecene $(\mathrm{C} 13: 1)$ & & hydrocarbon \\
\hline 18.625 & Tridecane (C13) & & hydrocarbon \\
\hline 19.983 & $\mathrm{~N}$-methyl Pyrrolidone-methyl carboxylate & & sugar \\
\hline 19.525 & Furan-3-carboxaldehyde, 2-methoxy-2,3-dihydro- & & sugar \\
\hline 20.6 & & trimethoxy benzene & \\
\hline 20.833 & methoxy methyl Benzoate & methoxy methyl Benzoate & lignin \\
\hline 21.142 & phenyl methyl propenoate & & lignin \\
\hline 21.217 & Tetradecene (C14:1) & & hydrocarbon \\
\hline 21.283 & Dodecanone (ket C12) & & cetone \\
\hline 21.425 & Tetradecane (C14) & & hydrocarbon \\
\hline 21.8 & & trimethoxy toluene & \\
\hline 22.2 & Dimethyl-tetrahydro-pyrimidinone & & sugar \\
\hline 23.625 & dimethoxy benzaldehyde & & lignin \\
\hline 23.717 & Methyl tetradecene & & hydrocarbon \\
\hline 23.892 & Pentadecene (C15:1) & & hydrocarbon \\
\hline 24.1 & Pentadecane (C15) & & hydrocarbon \\
\hline 24.683 & methyl dodecanoate $(\mathrm{C} 12 \mathrm{Me})$ & & acid \\
\hline 25.8 & & Dimethoxyacetophenone & \\
\hline 26.417 & dimethoxy methyl benzoate & dimethoxy methyl benzoate & lignin \\
\hline 27.425 & methyl nonenone & & cetone \\
\hline 28.833 & Heptadecane (C17) & & hydrocarbon \\
\hline 29.5 & & methyl tetradecanoate $(\mathrm{C} 14 \mathrm{Me})$ & \\
\hline 30.783 & hydroxy methoxy trimethyl methyl benzoate & & lignin \\
\hline 31.108 & Octadecene $(\mathrm{C} 18: 1)$ & & hydrocarbon \\
\hline 33.283 & Nonadecene (C19:1) & & hydrocarbon \\
\hline 33.7 & & methyl hexadecenoate $(\mathrm{C} 16: 1 \mathrm{Me})$ & \\
\hline 33.942 & methyl hexadecanoate & methyl hexadecanoate (C16Me) & acid \\
\hline 35.342 & Eicosene $(\mathrm{C} 20: 1)$ & & hydrocarbon \\
\hline 35.983 & methyl heptadecanoate & & acid \\
\hline 37.317 & Uncosene $(\mathrm{C} 21: 1)$ & & hydrocarbon \\
\hline 37.442 & methyl octadecenoate & methyl octadecenoate (C18:1Me) & acid \\
\hline 37.942 & methyl octadecanoate & methyl octadecanoate ( $\mathrm{C} 18 \mathrm{Me})$ & acid \\
\hline 38.5 & methyl nonadecenoate & methyl nonadecenoate (C19Me) & acid \\
\hline 39.6 & & Methyl hydroxy hexadecanoate & \\
\hline 40.28 & & dimethyl hexadecanedioate & \\
\hline 41.6 & methyl eicosanoate (C20Me) & methyl eicosanoate (C20Me) & acid \\
\hline 43.25 & & methyl uncosenoate (C21Me) & \\
\hline 43.3 & Tetracosene (C24) & & hydrocarbon \\
\hline 44.95 & methyldocosanoate (C22Me) & & acid \\
\hline 46.542 & & methyl methyldocosanoate (C22Me) & \\
\hline 48.058 & methyl tetracosanoate $(\mathrm{C} 24 \mathrm{Me})$ & methyl tetracosanoate (C24Me) & acid \\
\hline 50.958 & methyl Hexacosanoate & methyl Hexacosanoate (C26Me) & acid \\
\hline 53.45 & & Hentriacontane & \\
\hline 54.058 & Methyl octacosanoate & Methyl octacosanoate (C28Me) & acid \\
\hline 55.175 & & Sitosterol & \\
\hline 55.892 & Dotriacontene (C32) & & hydrocarbon \\
\hline 56.917 & & Cholesten-3-ol, acetate & \\
\hline 57.3 & & Pentatriacontane (C35) & \\
\hline 58.175 & Methyl triacontanoate (C33) & Methyl triacontanoate (C30Me) & acid \\
\hline
\end{tabular}

${ }^{a}$ Ret. Time $=$ retention time on the chromatogram. 

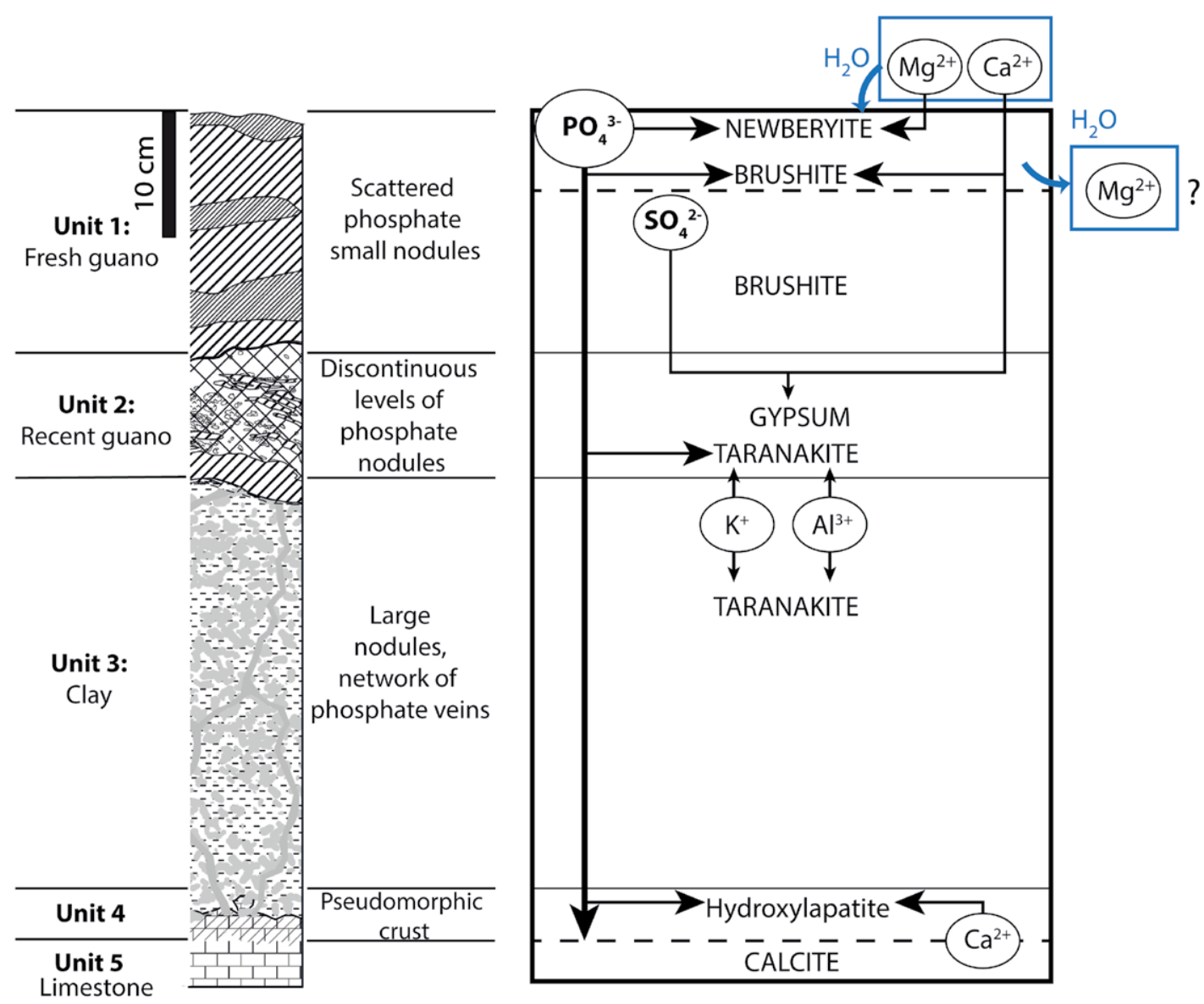

Figure 14. Schematic interpretation of the mineralogical evolution of La Fage Cave guano.

ties that are due to flow erosion. Unit 1 is similar to the upper unit in La Fage Cave, except for the lack of newberyite, which may reflect smaller amounts of $\mathrm{Mg}^{2+}$ ions provided by the host limestone. Monetite partially replaces brushite, possibly because sampling was done at the end of the dry season and the guano could have suffered some dehydration. Unit 2 corresponds to older guano mixed with detrital sediment. The lack of gypsum is assumed to result either

Figure 15. Schematic interpretation of the mineralogical evolution of Rancogne Cave guano.

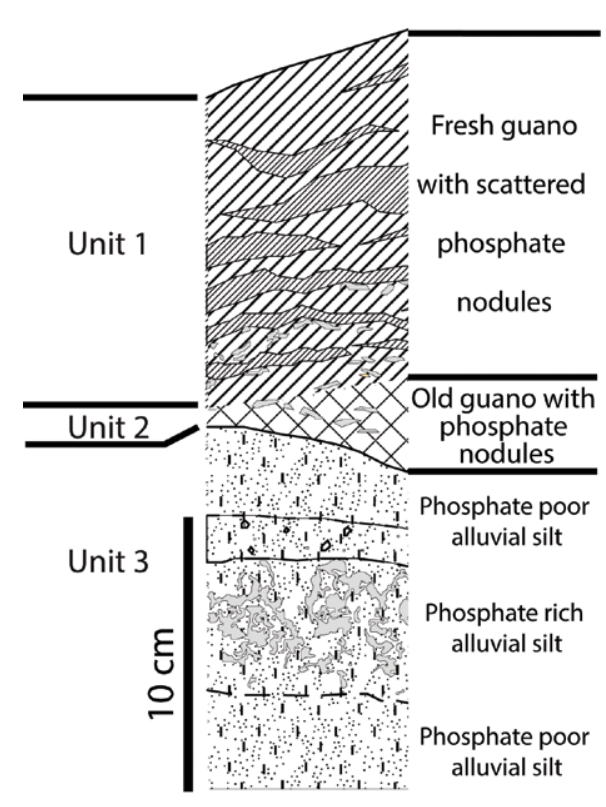

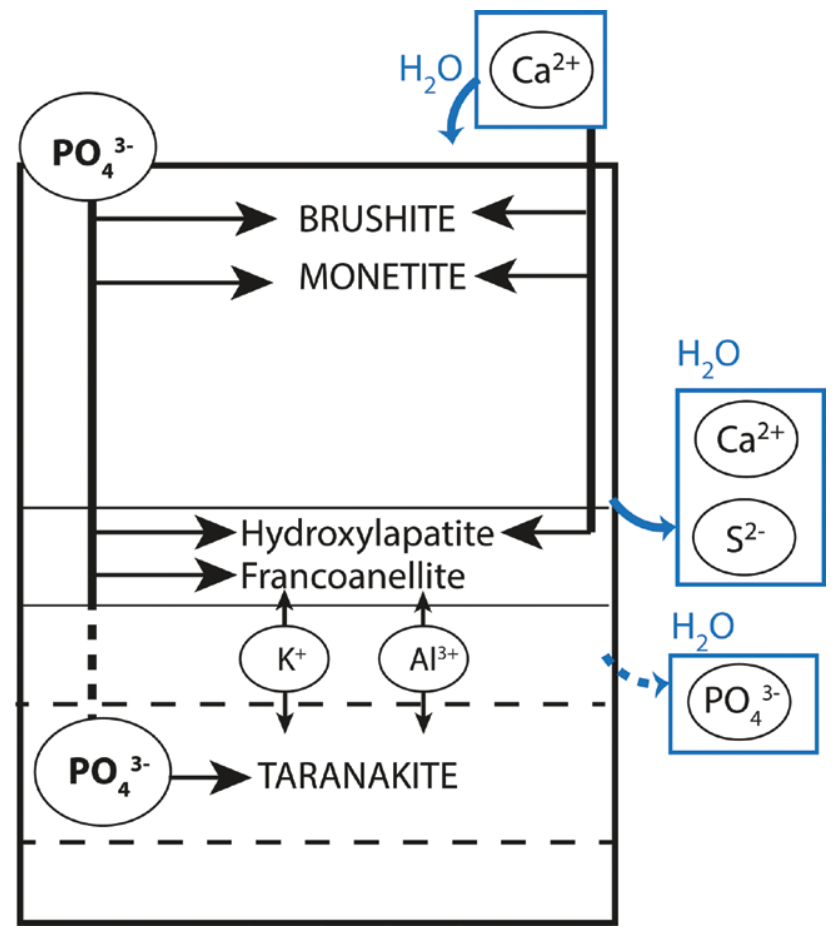


from dilution of the acidic solutions percolating through the guano mound, which prevented gypsum formation, or from subsequent dissolution of the crystals. Simultaneously, more stable minerals, such as hydroxylapatite and francoanellite, concentrated in degraded guano. Francoanellite is an uncommon mineral similar to taranakite, both in chemistry and structure (Table I). It has been reported in some caves (Balenzano et al., 1976; Marincea et al., 2012; Onac and Vereş, 2003; Queffelec et al., 2011) in close relationship to taranakite in clay sediments (Onac and Vereş, 2003), and its chemistry involves ions provided by the dissolution of clay minerals. As already noted above for monetite, sampling at the end of the dry season may explain the presence of this rare mineral instead of taranakite, the more hydrated mineral of the same phosphate group. The low amount of authigenic minerals in the underlying silty unit also suggests that the concentration in phosphate and sulfate ions remained low. Taranakite, which is poorly soluble in water, subsisted despite repeated flooding.

The guano sequence of Gavarnie Cave did not undergo similar phosphate accumulation. Possible factors involved are the periglacial climate that prevents organic matter degradation and the low availability of water (most water formed segregation ice in the deposits), that restricted ion redistribution within the guano mound. Another possible factor involved is that the choughs produce only limited amounts of phosphorus- and sulfur-rich compounds because of their dominantly herbivorous diet, when compared to the insectivorous bats. However, it has to be noted that frugivorous bats also produce guano, and degradation leads to the formation of abundant of phosphate minerals in subtropical and tropical contexts (Shahack-Gross et al., 2004; Queffelec et al., 2011, Royer et al., 2017).

Geochemical analysis reveals especially high $\mathrm{Cu}$ and $\mathrm{Zn}$ concentrations in bat guano both in La Fage and Rancogne caves. Hundreds of ppm $\mathrm{g} \mathrm{g} \mathrm{g}^{-1}$ of $\mathrm{Cu}$ and thousands of $\mathrm{ppm}$ of $\mathrm{Zn}$ have already been measured in recent bat guano (Fenolio et al., 2006; Zukal et al., 2015), as well as in an archeological context at Gorham's Cave (Monge et al., 2015). In this site, high $\mathrm{Cu}$ and $\mathrm{Zn}$ concentrations have been interpreted as being of anthropogenic origin (i.e. pollution). However, long-lasting bat settlement of the cave (Rodríguez-Vidal et al., 2014), rather, suggests that $\mathrm{Cu}$ and $\mathrm{Zn}$ is derived from bat guano. A recent study in southeast Asia (Wurster et al., 2015) also showed similar enrichment in transition metals in recent and ancient cave guano. Additionally, a guano-induced origin of $\mathrm{Zn}$-rich phosphates in a Bahamian cave has been proposed by Onac et al. (2009). The fact that these sediments from bat-inhabited, worldwide caves show remarkably high $\mathrm{Cu}$ and $\mathrm{Zn}$ concentrations makes it extremely unlikely that this could be due to recent pollution of the sites. The values measured in La Fage and Rancogne caves, both in fresh guano and in the underlying sediments, exceed by far the highest values measured in European soils and Quaternary sediments (De Vos et al., 2006). Cu values have been found to be lower than $260 \mu \mathrm{g} \mathrm{g}^{-1}$ in soils, $300 \mu \mathrm{g} \mathrm{g}^{-1}$ in humus, and $500 \mu \mathrm{g} \mathrm{g}^{-1}$ in modern floodplain sediments (De Vos et al., 2006). Therefore, values in excess of $1000 \mu^{-1}$ in units 1 and 5 in La Fage Cave and Unit 2 in Rancogne Cave have to be interpreted as resulting from local enrichment, due to the accumulation of bat guano. $\mathrm{Zn}$ also reaches the highest values recorded in Europe, which range from $1860 \mathrm{ug} \mathrm{g}^{-1}$ (soils) to $3060 \mathrm{\mu g} \mathrm{g}^{-1}$ (humus), while means are only $76 \mu \mathrm{g} \mathrm{g}^{-1}$ and $100 \mu \mathrm{g} \mathrm{g}^{-1}$, respectively. Zn reaches $1478 \mu \mathrm{g} \mathrm{g}^{-1}$ in floodplain sediments located near the Pierrefitte $\mathrm{Zn}-\mathrm{Pb}$ ore deposit in the French Pyrenees (De Vos et al., 2006). As for Cu, Zn values in excess of $4000 \mu \mathrm{g} \mathrm{g}{ }^{-1}$ in both La Fage and Rancogne caves have to be attributed to bat guano enrichment. It is also noteworthy that the highest values were measured in fresh guano (unit 1 of both sites) and in unit 4 of La Fage Cave, which is almost exclusively composed of authigenic minerals. In the first case, few minerals may act as $\mathrm{Cu}$ and $\mathrm{Zn}$ accumulators, and these elements are probably adsorbed on the organic matter, while in the second case they may be integrated in the authigenic minerals.

The analysis of organic matter by pyrolysis and thermochemolysis show noticeable differences between the two types of guano. On the one hand, the entomological origin of bat guano is demonstrated by the presence of alkenes/ alkanes doublets, coming from the pyrolysis of aliphatic biopolymers that are characteristic of insect cuticles. Chough guano, on the other hand, does not contain similar hydrocarbons, and its plant origin has been confirmed by the presence of abundant lignin and cellulosic components. As revealed by thermochemolysis, fatty acid abundance also differs. Fatty acids in bat guano may derive from plant remains, or more likely, from fungal development within the mound. Long-chain fatty acids, similar to the ones detected in the bat guano, have indeed been detected already in Mycelia sterilia (Stahl and Klug, 1996), a fungus identified on bat guano in Puerto Rico (Nieves-Rivera et al., 2009). The potential of this method to identify molecular compounds from bat excrements has to be underlined. Indeed, organic molecules from chitin, cellulose, and lignin have demonstrated as resistant to biodegradation through time (Stankiewicz et al., 1997, 1998). These may be used as markers for identifying bat guano in the archeological record and help distinguish potential sources of phosphate accumulation, whereas phosphate mineralogy alone does not provide clear indications.

\section{Conclusion}

The study of recent guano in caves allows better understanding of the main stages of its degradation and mineralization in a temperate, humid context. It also provides the opportunity to compare guano from bats and from choughs, another potential contributor to organic matter deposition in caves. The deposition, degradation and chemical evolution of a mound of bat guano leads to massive production of phosphorous and sulfur compounds that react with local cat- 
ions to produce specific minerals. This study demonstrates the ubiquity of brushite and hydroxylapatite in calcareous contexts and the presence of taranakite or francoanellite when clay interacts with the acidic solutions. The formation of newberyite depends on the availability of magnesium ions provided by the host rocks. Water availability also plays a key role in guano degradation by the soil microfauna, in the degree of hydration of the authigenic minerals formed, and in their sediment preservation. Bat guano was found to contain large amounts of phosphate accumulation. In the investigated cave, chough guano did not lead to the production of neoformed minerals, perhaps mainly because of local conditions such as cold temperature and poor water availability (mostly frozen). The diversified and low trophic-level diet of the choughs may also be involved in the lower production of phosphates.

The early degradation stages of bat guano have little potential for preservation in the fossil record of southwest France since the main authigenic minerals are soluble or unstable over long periods in humid environments. In addition, gypsum may derive from sources other than guano, particularly in arid or coastal environments. Hydroxylapatite is common in archeological sites and may also come from other sources such as bones or coprolites. Newberyite and taranakite, which are less frequent, can be used as proxies for acidic solutions interacting with minerals in karstic sediments. These phosphate minerals, however, are almost absent in the archeological record from southwest France. This may reflect their instability in calcareous contexts that remained dominantly alkaline over the long term. However, since newberyite has been identified in Grotte XVI (Karkanas et al., 2002), thus testifying to its ability to be preserved in regional caves at least locally, the lack of such minerals may alternatively indicate that bat guano was not the main source of phosphate accumulation in most sites.

In contrast, this study suggests strongly that both the composition of organic matter and the content in transition metals may provide useful arguments for identifying the phosphate sources. In particular, aliphatic biopolymers, typical of insect cuticles, can be identified using pyrolysis on recent bat guano. Since these compounds are known to be resistant over time, they may potentially be identified in Pleistocene cave sediments. $\mathrm{Cu}$ and $\mathrm{Zn}$ concentrations have shown to be unusually high both in bat guano and in the underlying sediments containing neoformed minerals. Similar concentrations of $\mathrm{Cu}$ and $\mathrm{Zn}$ do not occur naturally in the study region or in other parts of southwest France, and obviously come from guano.

\section{ACKNOWLEDGMENTS}

We are grateful to Vincent Nicolas, Catherine Rouveron, Danielle Doucet and her husband for allowing us to sample the La Fage and Rancogne caves. We also acknowledge Eric Lebraud (UPR 9058 ICMCB) for XRD analysis, Nadia Cantin (UMR 5060 IRAMAT-CRP2A) for the TOPAS access, Dominique Poirier and Henri Etcheber (UMR 5805 EPOC) for $\mathrm{pH}$ and the LECO analyses. This study was partly conducted in the Collective Research Program "Caves of Guadeloupe: geological, paleontological and archaeological studies" funded by the Regional Service of Archaeology, the Guadeloupe Regional Council and the DEAL of Guadeloupe as an realistic approach for better understanding Caribbean guano deposits. This research was also supported by the LaScArBx research program (ANR-10-LABX-52). Four anonymous reviewers are thanked for their thorough comments on previous versions of this manuscript. These comments have helped to markedly improve it.

\section{References}

Ajas, A., Bertran, P., Lemée, L., and Queffelec, A., 2013, Stratigraphy and Palaeopedology of the Palaeolithic Cave Site of Combe-Saunière, Southwest France: Geoarchaeology, p. 1-18, http://doi:10.1002/gea.21451.

Baize, D., 2000, Guide des analyses en pédologie: 2e édition, revue et augmentée: Editions Quae.

Balenzano, F., Dell'Anna, L., and Di Pierro, M., 1976, Francoanellite, H6K3AI5(PO4)8.13H2O, a new mineral from the caves of Castelagna, Puglia, southern Italy: Neues Jahrbuch für Mineralogie Abhandlungen, p. 49-57.

Beaulieu, J.-L., Debard, E., Guérin, C., Jammot, D., Petter, F., Renault, P., and Vilain, R., 1973, Le gisement paléontologique pléistocène des Abîmes de la Fage à Noailles (Corrèze): Lyon, Nouvelles Archives du Museum d'Histoire Naturelle de Lyon.

Bertran, P., 1999, Dynamique des dépôts de la grotte Bourgeois-Delaunay (La Chaise-de-Vouthon, Charente) : apport de la micromorphologie / Depositional processes in the Bourgeois-Delaunay Cave (La Chaise-de-Vouthon, Charente, France): micromorphological approach: Paléo, v. 11, p. 9-18, http://doi:10.3406/pal.1999.1168.

Bird, M.I., Boobyer, E.M., Bryant, C., Lewis, H.A., Paz, V., and Stephens, W.E., 2007, A long record of environmental change from bat guano deposits in Makangit Cave, Palawan, Philippines: Earth and Environmental Science Transactions of The Royal Society of Edinburgh, v. 98 , p. 59-69, http://doi:10.1017/S1755691007000059.

Blomquist, G.J., 2010, Structure and analysis of insect hydrocarbons, in Insect hydrocarbons: Biology, biochemistry, and chemical ecology, New York, Blomquist \& Bagnères, p. 19-34.

Boistelle, R., Abbona, F., and Madsen, H.L., 1983, On the transformation of struvite into newberyite in aqueous systems: Physics and Chemistry of minerals, v. 9, p. 216-222.

Bridge, P.J., 1973, Guano minerals from Murra-el-elevyn Cave, Western Australia: Mineralogical Magazine, v. 39, p. 467-469.

Carrión, J.S., Scott, L., and Marais, E., 2006, Environmental implications of pollen spectra in bat droppings from southeastern Spain and potential for palaeoenvironmental reconstructions: Review of Palaeobotany and Palynology, v. 140, p. 175-186, http://doi:10.1016/j.revpalbo.2006.03.007.

Courty, M.A., Goldberg, P., and MacPhail, R., 1989, Soils and micromorphology in archaeology: Cambridge.

De Vos, W., Tarvainen, T., Salminen, R., Reeder, S., De Vivo, B., Lima, A., and others, 2006, Geochemical atlas of Europe. Part 2. Interpretation 
of geochemical maps, additional tables, figures, maps, and related publications: Geological Survey of Finland, v. 2.

Dendaletche, C., 1997, Les Pyrénées. La vie sauvage en montagne et celle des hommes: Paris, Delachaux and Niestlé, La bibliothèque du naturaliste, $335 \mathrm{p}$.

Dumitraş, D.-G., Marincea, S., Bilal, E., and Hatert, F., 2008, Apatite-(CaOH) in the fossil bat guano deposit from the "dry" Cioclovina cave, Şureanu Mountains, Romania: The Canadian Mineralogist, v. 46, p. 431-445, http://doi:10.3749/canmin.46.2.431.

Engel, A.S., Stern, L.A., and Bennett, P.C., 2004, Microbial contributions to cave formation: New insights into sulfuric acid speleogenesis: Geology, v. 32, p. 369-372, http://doi:10.1130/G20288.1.

Fenolio, D.B., Graening, G.O., Collier, B.A., and Stout, J.F., 2006, Coprophagy in a cave-adapted salamander; the importance of bat guano examined through nutritional and stable isotope analyses: Proceedings of the Royal Society B: Biological Sciences, v. 273, p. 439-443, http:// doi:10.1098/rspb.2005.3341.

Fiore, S., and Laviano, R., 1991, Brushite, hydroxylapatite, and taranakite from Apulian caves (southern Italy): New mineralogical data: American Mineralogist, v. 76, p. 1722-1727.

Forray, F.L., Onac, B.P., Tanţău, I., Wynn, J.G., Tămaş, T., Coroiu, I., and Giurgiu, A.M., 2015, A Late Holocene environmental history of a bat guano deposit from Romania: an isotopic, pollen and microcharcoal study: Quaternary Science Reviews, v. 127, p. 141-154, http:// doi:10.1016/j.quascirev.2015.05.022.

Geantă, A., Tanţău, I., Tămaş, T., and Johnston, V.E., 2012, Palaeoenvironmental information from the palynology of an 800 -year-old bat guano deposit from Măgurici Cave, NW Transylvania (Romania): Review of Palaeobotany and Palynology, v. 174, p. 57-66, http://doi:10.1016/j.revpalbo.2011.12.009.

Géroudet, P., 2010, Les passereaux d'Europe Tome 2 - de la bouscarle aux bruants: Paris, Delachaux and Niestlé, 512 p.

Goldberg, P., and Nathan, Y., 1975, The phosphate mineralogy of et-Tabun cave, Mount Carmel, Israel: Mineralogical Magazine, v. 40, p. 253-258.

Guilloré, P., 1980, Méthode de fabrication mécanique et en série des lames minces: Institut National Agronomique, Paris-Grignon, France.

Hill, C.A., and Forti, P., 1997, Cave minerals of the world: Huntsville, Alabama, 464 p.

Hosono, T., Uchida, E., Suda, C., Ueno, A., and Nakagawa, T., 2006, Salt weathering of sandstone at the Angkor monuments, Cambodia: identification of the origins of salts using sulfur and strontium isotopes: Journal of Archaeological Science, v. 33, p. 1541-1551, http://doi:10.1016/j. jas.2006.01.018.

Hutchinson, G.E., 1950, The biogeochemistry of vertebrate excretion: New-York, Survey of existing knowledge of biogeochemistry 3 , v. 96,554 p.

Karkanas, P., Bar-Yosef, O., Goldberg, P., and Weiner, S., 2000, Diagenesis in Prehistoric Caves: the Use of Minerals that Form In Situ to Assess the Completeness of the Archaeological Record: Journal of Archaeological Science, v. 27, p. 915-929, http://doi:10.1006/jasc.1999.0506.

Karkanas, P., Rigaud, J.-P., Simek, J.F., Albert, R.M., and Weiner, S., 2002, Ash Bones and Guano: a Study of the Minerals and Phytoliths in the Sediments of Grotte XVI, Dordogne, France: Journal of Archaeological Science, v. 29, p. 721-732, http://doi:10.1006/jasc.2001.0742.

Kolattukudy, P.E., 1976, Chemistry and biochemistry of natural waxes: Elsevier Scientific Pub. Co.

Laroulandie, V., 2004, Exploitation des ressources aviaires durant le Paléolithique en France: bilan critique et perspectives, in J.-P. Brugal, J. Desse (dir.), Petits Animaux et Sociétés Humaines. Du complément alimentaire aux ressources utilitaires. Actes des XXIVe rencontres internationales d'archéologie et d'histoire, Antibes, 23-25 Octobre 2003, APDCA, p. 163-172.

Lefavrais-Raymond, A., Boissonas, J., Talbert, J.-C., Feys, R., Raynal, J.-P., David, L., Bonfils, P., and Barruol, J., 1976, Notice explicative de la feuille Brive-la-Gaillarde à 1/50.000è.

Li, X., Arai, H., Shimoda, I., Kuraishi, H., and Katayama, Y., 2008, Enumeration of Sulfur-Oxidizing Microorganisms on Deteriorating Stone of the Angkor Monuments, Cambodia: Microbes and Environments, v. 23, p. 293-298, http://doi:10.1264/jsme2.ME08521.

Marincea, Ş., Dumitraş, D.G., Diaconu, G., and Fransolet, A.-M., 2012, Mineralogical data on the bat guano deposit from Gura Ponicovei cave (Almaj Mountains, Romania): Romanian Journal of Earth Science.

Marincea, S., Dumitras, D.-G., Dianocu, G., and Bilal, E., 2004, Hydroxylapatite, brushite and ardealite in the bat guano deposit form Pestera Mare de la Meresti, Persani Mountains, Romania: Neues Jahrbuch für Mineralogie - Monatshefte, v. 10, p. 464-488.

Marincea, S., Dumitras, D., and Gibert, R., 2002, Tinsleyite in the "dry" Cioclovina Cave (Sureanu Mountains, Romania): the second occurrence: European Journal of Mineralogy, v. 14, p. 157-164, http://doi:10.1127/0935-1221/2002/0014-0157.

Martini, J.E., and Kavalieris, I., 1976, Mineralogy of Transvaal cave formations: South African Speleological Association Bulletin, v. 17, p. 11-12.

McLafferty, F.W., 1959, Mass spectrometric analysis. Molecular rearrangements: Analytical Chemistry, v. 31, p. 82-87.

Mizutani, H., McFarlane, D.A., and Kabaya, Y., 1992, Carbon and Nitrogen Isotopic Signatures of Bat Guanos as Record of Past Environments: Journal of the Mass Spectrometry Society of Japan, v. 40, p. 67-82, http://doi:10.5702/massspec.40.67.

Monge, G., Jimenez-Espejo, F.J., García-Alix, A., Martínez-Ruiz, F., Mattielli, N., Finlayson, C., Ohkouchi, N., Sánchez, M.C., de Castro, J.M.B., Blasco, R., Rosell, J., Carrión, J., Rodríguez-Vidal, J., and Finlayson, G., 2015, Earliest evidence of pollution by heavy metals in archaeological sites: Scientific Reports, v. 5, http://doi:10.1038/srep14252.

Nieves-Rivera, Á., Santos-Flores, C., Dugan, F., and Miller, T., 2009, Guanophilic fungi in three caves of southwestern Puerto Rico: International Journal of Speleology, v. 38, p. 61-70, http://doi:10.5038/1827-806X.38.1.7.

Onac, B.P., Ettinger, K., Kearns, J., and Balasz, I.I., 2005, A modern, guano-related occurrence of foggite, $\mathrm{CaAl}(\mathrm{PO} 4)(\mathrm{OH}) 2 \cdot \mathrm{H} 2 \mathrm{O}$ and churchite-(Y), YPO4 $2 \mathrm{H} 2 \mathrm{O}$ in Cioclovina Cave, Romania: Mineralogy and Petrology, v. 85, p. 291-302, http://doi:10.1007/s00710-005-0106-4.

Onac, B.P., Mylroie, J.E., and White, W.B., 2001, Mineralogy of cave deposits on San Salvador Island, Bahamas: Carbonates and Evaporites, v. 16, p. 8-16, http://doi:10.1007/BF03176222.

Onac, B.P., Sumrall, J., Mylroie, J.E., and Kearns, J., 2009, Cave Minerals of San Salvador Island, Bahamas: University of South Florida Tampa Library.

Onac, B.P., and Vereş, D.Ş., 2003, Sequence of secondary phosphates deposition in a karst environment: evidence from Măgurici Cave (Romania): European Journal of Mineralogy, v. 15, p. 741-745, http://doi:10.1127/0935-1221/2003/0015-0741.

Parker, D.I., Lawhead, B.E., and Cook, J.A., 1997, Distributional Limits of Bats in Alaska: Arctic, v. 50, p. $256-265$.

Paul, E.A., 2007, Soil microbiology, ecology, and biochemistry: San Diego, California, USA, Academic Press.

Perrenoud, C., 1993, Origine et mise en place des paragenèses phosphatées de remplissages karstiques quaternaires. Etude micromorphologique des sédiments de la Caune de l'Arago (Tautavel, Pyrénées-Orientales) et de la Baume Bonne (Quinson, Alpes-de-Haute-Provence) [PhD dissertation]: Paris.

Puşcaş, C.M., Kristaly, F., Stremţan, C.C., Onac, B.P., and Effenberger, H.S., 2014, Stability of cave phosphates: Case study from Liliecilor Cave (Trascău Mountains, Romania): Neues Jahrbuch f??r Mineralogie - Abhandlungen: Journal of Mineralogy and Geoche, v. 191, p. 157-168, 
http://doi:10.1127/0077-7757/2014/0254.

Queffelec, A., Lenoble, A., and Lebraud, E., 2011, Remplissage des cavités de Guadeloupe : caractérisation par diffraction des rayons $X$ pour une meilleure connaissance des environnements passés, in 9ème colloque Rayons X et Matière, Tours, http://doi:10.13140/ RG.2.2.12635.98084.

Quénéa, K., Derenne, S., González-Vila, F.J., González-Pérez, J.A., Mariotti, A., and Largeau, C., 2006, Double-shot pyrolysis of the non-hydrolysable organic fraction isolated from a sandy forest soil (Landes de Gascogne, South-West France): Comparison with classical Curie point pyrolysis: Journal of Analytical and Applied Pyrolysis, v. 76, p. 271-279, http://doi:10.1016/j.jaap.2005.12.007.

Rezanka, T., 1989, Very-long-chain fatty acids from the animal and plant kingdoms: Progress in Lipid Research, v. 28, p. 147-187, http:// doi:10.1016/0163-7827(89)90011-8.

Řezanka, T., and Mareš, P., 1987, Unusual and very long-chain fatty acids produced by Basidiomycetes: Journal of Chromatography A, v. 409, p. 390-395, http://doi:10.1016/S0021-9673(01)86818-7.

Rietveld, H., 1969, A profile refinement method for nuclear and magnetic structures: Journal of applied Crystallography, v. 2, p. 65-71.

Rinaudo, C., and Abbona, F., 1988, A contribution to the study of the crystal chemistry of calcium sulfate phosphate hydrate: Mineralogical and Petrographica Acta, v. 31, p. 95-105.

del Río, J.C., and Hatcher, P.G., 1998, Analysis of aliphatic biopolymers using thermochemolysis with tetramethylammonium hydroxide (TMAH) and gas chromatography-mass spectrometry: Organic Geochemistry, v. 29, p. 1441-1451, http://doi:10.1016/S0146-6380(98)00070-9.

Rodríguez-Vidal, J., d’Errico, F., Pacheco, F.G., Blasco, R., Rosell, J., Jennings, R.P., Queffelec, A., Finlayson, G., Fa, D.A., López, J.M.G., Carrión, J.S., Negro, J.J., Finlayson, S., Cáceres, L.M., et al., 2014, A rock engraving made by Neanderthals in Gibraltar: Proceedings of the National Academy of Sciences, v. 111, p. 13301-13306, http://doi:10.1073/pnas.1411529111.

Royer, A., Malaizé, B., Lécuyer, C., Queffelec, A., Charlier, K., Caley, T., and Lenoble, A., 2017, A high-resolution temporal record of environmental changes in the Eastern Caribbean (Guadeloupe) from 40 to 10 ka BP: Quaternary Science Reviews, v. 155, p. 198-212, http://doi:10.1016/j. quascirev.2016.11.010.

Sakae, T., and Sudo, T., 1975, Taranakite from the Oniwo-Iwaya cave at Hiroshima Prefecture, Japan: a new occurence: American Mineralogist, v. 60 , p. 331-334.

Shahack-Gross, R., Berna, F., Karkanas, P., and Weiner, S., 2004, Bat guano and preservation of archaeological remains in cave sites: Journal of Archaeological Science, v. 31, p. 1259-1272, http://doi:10.1016/j.jas.2004.02.004.

Stahl, P.D., and Klug, M.J., 1996, Characterization and differentiation of filamentous fungi based on fatty acid composition: Applied and Environmental Microbiology, v. 62, p. 4136-4146.

Stankiewicz, B.A., Briggs, D.E.G., Evershed, R.P., Flannery, M.B., and Wuttke, M., 1997, Preservation of Chitin in 25-Million-Year-Old Fossils: Science, v. 276, p. 1541-1543, http://doi:10.1126/science.276.5318.1541.

Stankiewicz, B.A., Poinar, H.N., Briggs, D.E.G., Evershed, R.P., and Poinar, G.O., 1998, Chemical preservation of plants and insects in natural resins: Proceedings of the Royal Society B: Biological Sciences, v. 265, p. 641-647.

Tegelaar, E.W., De Leeuw, J.W., and Holloway, P.J., 1989, Some mechanisms of flash pyrolysis of naturally occurring higher plant polyesters: Journal of Analytical and Applied Pyrolysis, v. 15, p. 289-295.

Weiner, S., Goldberg, P., and Bar-Yosef, O., 2002, Three-dimensional distribution of minerals in the sediments of Hayonim Cave, Israel: diagenetic processes and archaeological implications: Journal of Archaeological Science, v. 29, p. 1289-1308.

Whitney, D.L., and Evans, B.W., 2010, Abbreviations for names of rock-forming minerals: American mineralogist, v. 95, p. 185-187.

Wurster, C.M., Munksgaard, N., Zwart, C., and Bird, M., 2015, The biogeochemistry of insectivorous cave guano: a case study from insular Southeast Asia: Biogeochemistry, v. 124, p. 163-175, http://doi:10.1007/s10533-015-0089-0.

Wurster, C.M., Patterson, W.P., McFarlane, D.A., Wassenaar, L.I., Hobson, K.A., Athfield, N.B., and Bird, M.I., 2008, Stable carbon and hydrogen isotopes from bat guano in the Grand Canyon, USA, reveal Younger Dryas and 8.2 ka events: Geology, v. 36, p. 683-686, http://doi:10.1130/ G24938A.1.

Zukal, J., Pikula, J., and Bandouchova, H., 2015, Bats as bioindicators of heavy metal pollution: history and prospect: Mammalian Biology Zeitschrift für Säugetierkunde, v. 80, p. 220-227, http://doi:10.1016/j.mambio.2015.01.001. 